\title{
Change in Control and Firm Performance
}

\author{
Yin-Hua Yeh \\ Graduate Institute of Finane, National Chiao Tung University \\ 1001 Ta-Hsueh Rd., Hsinchu City, Taiwan 30010 \\ Tel: 886-3513-1294Ｅ-mail: yhyeh@nctu.edu.tw \\ Pei-Gi Shu \\ Department of Business Administration, Fu Jen Catholic University \\ 510, Zhongzheng Rd., Xinzhuang Dist., New Taipei City 24205, Taiwan \\ E-mail: 036047@mail.fju.edu.tw
}

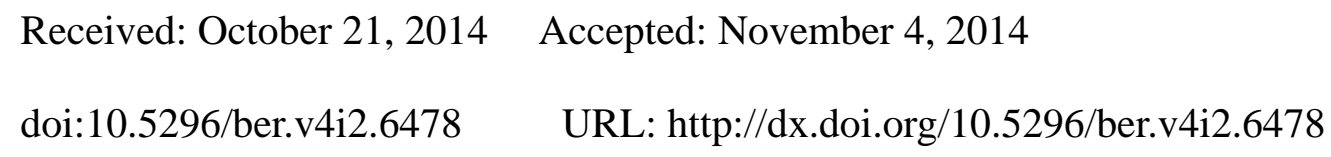

\begin{abstract}
Whether firms that experienced change in control perform better or worse than before the change remains a puzzling issue. In this study we investigate the firms that experienced change in control and find that poor performing firms tend to be the takeover targets; however, these firms performed even worse after change of control. We find that corporate governance dictates the post-change performance measures. The proportion of directors controlled by the controlling shareholder is negatively related to the post-change performance measures. In contrast, the proportion of directors controlled by the second controlling shareholder is positively related to the post-change performance measures. Furthermore, the performance measures of the targets improved when the controlling shareholder entitled high cash flow rights. Finally, the change-in-control firms are more likely to be trapped in financial distress when the controlling shareholders deeply involved in the board.
\end{abstract}

Keywords: Corporate Governance, Change in Control, Controlling Shareholder 
1. Introduction

Recent corporate scandals have attracted the attention of different constituencies on reforming corporate governance. Corporate agents at the most senior levels, including controlling owners, CEOs and chairs of boards of directors, play important roles in corporate governance and any significant reforms have to encompass their roles. The focus is on the right track since these people setting tone at the top through examples and actions are crucial to dictate the follow-on performance of underlying firm. . However, there are at least two aspects that need to be further uncovered. First of all, could it be possible to find a forum portraying the importance of top-level agents other than the happening that the top-level agents are accused of being key players in the corporate malfeasance? Focusing on the fraudulent event might at best provides hindsight to investors and fails to discern firms with good corporate governance structure from ones that are in question but not to the level of triggering the event. In other words, we are only partially convinced that fraudulent firms are associated with inferior governance structure, but not vice versa. Secondly, the fact that most progressing reforms up to date mainly target the legal rather than the ethical obligations of directors might be ineffectual (Schwartz, Dunfee, and Kline, 2005). In this paper, we focus on providing the empirical evidences for the former and leave the latter for further discussions.

In this paper we select a sample of firms that have experienced change in control through mergers and acquisitions. Even though these firms tend to be poor performing ones that accompanied with unqualified managers ${ }^{1}$, most of them have not been to the brink of financial distress or being legally accused of fraudulence. These firms provide a splendid forum to test the issue of how and why a change in control, especially the top-level governance structure, would affect a firm's performance. Moreover, these change-in-control firms are applicable to the test between corporate governance and performance because these new controlling shareholders are less emotionally connected ${ }^{2}$ to the firms and are therefore less affected by ethical values that are beneficial to firm's long-run prosperity. In other words, our sample could potentially segregate the effect of corporate governance and that of ethical values on firm's performance. This is a less investigated issue with some exceptions that mainly focus on post-change performance

\footnotetext{
1 These firms tend to be disciplined by market of corporate control taking at several forms, including takeover, proxy contest, management replacement, and initiation of adverse publicity (Butz, 1994; Manne, 1965; Martin and McConnell, 1991; Morck, Shleifer, and Vishny, 1989; Palepu, 1985; Shleifer and Vishny, 1986).

${ }^{2}$ Gaudine and Thorne (2001) develop the first model describing the role of emotion in ethical decision processes, proposing how affective valence and arousal influence various aspects of ethical decision making. However, not all same-valence emotions influence behavior in the same way (Lee and Allen, 2002; Lerner and Keltner, 2000; Lewis, 2000; Weiss et al., 1999). Connely et al. (2004) illustrate that passive emotions would be less related to ethical choices than active emotions.
} 
measures while not directly connect them to corporate governance ${ }^{3}$.

In this study we ask a rudimentary question as why the market of corporate control disciplines poor-performing managers while does not guarantee improvement of post-change performance? If the post-change performance is due to chance, it should not be significantly related to top-level constituencies of the target firms. However, this is improbable though not impossible for the controlling shareholders to squander their money in acquisitions. Demsetz and Lehn (1985) propose that investors have incentive to purchase blocks of stock when the expected benefits of doing so outweigh the expected costs $^{4}$. If this were the case, controlling owners who took over another firm would had pictured the private benefits of control that is something beyond dividend payment and capital gains. For example, they could have proportional claim if the firm operates properly or siphon disproportional stakes of the firm if it were trapped in troubles. Our evidences support the importance of corporate governance structure that manifests the controlling shareholder's motives on affecting the post-change performance.

Based on ownership structure, we hypothesize two complementary arguments that predict the post-change performance of the target firms. According to La Porta et al. (2002) and Claessens et al. (2002), the positive incentive effect indicates that, with the increase of cash flow rights, the acquirer is more willing to have the firm run properly and that is directly connected to his own wealth. Moreover, when the acquirer has more cash flow rights, the minority shareholders could discipline him by discounting stock price. Therefore, we hypothesize that, with the increase of the acquirer's cash flow rights, the interests between the controlling owner and minority shareholders are well aligned and results in improvement of post-change performance of firms that change in control.

The other counterargument indicates that the entrenched controlling owner may opportunistically engage in outright expropriation of minority interest, i.e. the controlling shareholder benefits from self-dealing deeds through related-party transactions or exercise de facto expropriation through the pursuit of not value-maximizing objectives. When the acquirer levers control through pyramidal structure, cross shareholding, or dual capitalization rather than direct cash flow investment, it would be easier for him/her to control the board membership and less subjected to the governance from board. With the higher voting rights from leverage, he would be less likely to become the acquired target and less bounded by the discipline from the corporate control market. When the

\footnotetext{
${ }^{3}$ Flower and Schmidt (1989) find no significant improvement of the post-change performance of the target firms. Agrawal, Jaffe, and Mandelker (1992) find negative market-wide or economy-wide adjusted returns. In contrast, Healey, Palepu and Ruback (1992) evidence the improvement of asset productivity for 50 largest U.S. acquisitions. Bethel, Liebeskind, and Opler (1998) indicate that activist bock purchases were followed by increases in asset divestitures, decreases in mergers and acquisitions, and abnormal share price appreciations.

${ }^{4}$ The costs of influencing corporate performance include the loss of portfolio diversification, expenditure of resources to monitor management, fight potential legal challenges, mount proxy contest, and the like.
} 
controlling shareholder has voting rights afar from his cash flow rights, he might extract wealth from the firm, receive the entire benefit, and only bear a fraction of the cost.

Besides the ownership structure, the controlling owner might exert power through a dominant control over the board structure, i.e. taking more seats on the board of directors and the board of supervisors. The proportion of board membership controlled by the new controlling shareholder manifests ambition of wealth exploitation and therefore affects the post-change performance.

Xiang and Zhang (1996) indicate that the emergence of a second large shareholder deters the controlling shareholder's opportunism and reduces the social inefficiency from his expropriation of minority wealth. Yeh, Lee and Shu (2008) conclude a similar finding and portray the importance of the existence of a second controlling shareholder. Not only has the existence mattered, would we expect that a higher proportion of board membership controlled by the second controlling shareholder is positively related to the post-change performance.

In this study we examine the positive incentive hypothesis and wealth expropriation hypothesis for the new controlling shareholder. We find that the variables pertaining to the ownership structure and board structure significantly affect the post-change performance of the target firms even after controlling the variables explored in previous literature, such as the type of block purchaser ${ }^{5}$, the size effect ${ }^{6}$, leverage ${ }^{7}$, and industry relations ${ }^{8}$.

Our sample consists of the listed firms that changed in control from 1991 through 1999. The change in corporate control is recognized only when the joint condition that the controlling shareholder is replaced and that the new controlling shareholder obtains more than $20 \%$ voting rights or controls more than half of board membership is satisfied ${ }^{9}$. We

\footnotetext{
${ }^{5}$ Bethel, Liebeskind, and Opler (1998) classify bolckholders into three groups: activist blockholders, financial blockholders, and strategic investors. They show that activist blockholders tend to divert firm policies to divest assets and decrease in M\&As and lead to abnormal share price appreciations. Financial blockholders who are less likely to adopt value-decreasing policies (Jarrell and Poulsen, 1987; Brickley, Lease, and Smith, 1988) are beneficial to firm's performance. Healy, Palepu, and Ruback (1997) indicated that strategic takeovers, which are generally friendly transactions involving stock and firms in overlapping businesses, are more profitable than financial deals.

6 Ambrose and Megginson (1992) and Comment and Schwert (1995) show that takeovers are less frequent in large firms. Bethel, Liebeskind, and Opler (1998) find that firms targeted by activist investors tended to be smaller, possibly due to the high cost of assembling significant share blocks in large firms.

7 Debt ratio have two possible effects on the value of the firm. According to Morck et al (1988) and Craswell et al. (1997), it captures the value of tax shields that is beneficial to corporate value while excessive use of it would lead to higher expected cost of financial distress and lower corporate value.

8 Healy, Palepu, and Ruback (1997) illustrated that acquisitions with firms in overlapping businesses are more profitable than those with firms in unrelated businesses.

${ }^{9} \mathrm{La}$ Porta et al. (1999) and Claessens et al. (2000) use cut off of $20 \%$ to illustrate the existence of controlling shareholder. It is possible that investors holding merely $10 \%$, the minimum disclosure requirement, sit on the board. However, this is not the case of change in control because the controlling shareholder remains unchanged. According to Corporation Law in Taiwan investors holding more than 5\% have the right to call an extraordinary general meeting to change management. However, this is not the case neither suffice the controlling shareholder remains unchanged. If the dissident holding merely $5 \%$ of shareholding successfully changes management, he/she must have done it
} 
include firms with tractable three-year financial performance measures and stock returns before and after the change in control. Repetitive while non-overlapped cases are also included in our sample. No firms were delisted in three years after the change in control that means that the sample is not biased toward larger and healthier firms. In total our sample consists of 46 observations. The empirical results verify our research hypotheses that the higher the proportion of directorates or supervisors represented by the controlling shareholder, the lower the post-change performance. In contrast, the second controlling shareholder provides a surveillance function to prevent the controlling shareholder from exploiting the wealth of the minority shareholders. Moreover, the post-change performance of the target is higher when the controlling shareholder has higher cash flow rights. Finally, we find that the target firm is prone to be trapped in financial distress if the controlling shareholder purposely involved in the board structure.

Even though previous literatures have indicated that firms under little governance perform poorer (La Porta et al., 2002; Claessens et al., 2002, Shleifer and Vishny, 1997, and among others), so far as we know there is little literature to incorporate corporate governance with the momentous change in corporate control and to make inter-temporal comparisons of change in governance structure and change in firm's performance. An inter-temporal comparison is especially meaningful when firms confronted with momentous change in control, which is different from the cross-sectional comparisons pervasively used in previous studies. Our findings potentially contribute to the literature of corporate governance and the literature of market of corporate control as to illustrate that the acquirer's positive incentive and wealth-exploiting ambition significantly affect the post-change performance.

\section{Corporate Governance in Taiwan}

Unlike the diversified structure in the U.S. the ownership structure in Taiwan as well as in most countries around the world is characterized as a high degree of concentration in hand of a predominant family ${ }^{10}$. Family generally oversees the development of a business firm from its inception, and continues to play a dominant role in decision-making process even after its going public. Thus, Taiwanese listed companies are generally owned, controlled, and managed by families, which is in marked contrast to their U.S. and Japanese-Germanic counterparts. In general the governance structure in Taiwan is characterized by the absence of effective audit committees, low institutional ownership,

through proxy fight as to control more than half of board membership. This meets our definition. There was no explicit rule in the sampling period to stipulate the maximum holding a company can acquire before launching a takeover bid. Most takeover cases in Taiwan are through open market purchase.

${ }^{10}$ For example, Yeh, Lee, and Woidtke (2001) find that Taiwanese listed companies have similar ownership characteristics to publicly traded companies in most countries around the world. They are characterized by a high degree of ownership in general and are predominantly family-controlled (see La Porta et al., 1999; Claessens, Djankov, and Lang, 2000; and Faccio and Lang, 2002 for ownership characteristics in countries around the world). 
and inactive market for corporate control.

The corporate boards in Taiwan are comprised of two separate organizations that are a board of directors and a board of supervisors. Directorship, at minimum composed of three members, is responsible for involving management practices, appointing (dismissing) and compensating management team and external auditors, legal representation of company, and approving equity and debt issues. Momentous decisions need to be voted in the board. In our sampling period the Rule did not require independent directors to be included in the board.

Supervisors, on the other hand, do not involve in management practice nor participate in the vote. They are responsible for scrutinizing the decisions made by directors, reviewing and auditing company reports, and resolving the disputes between shareholders and directors. Though superficially resemble to its Germanic counterpart, the supervisory board in Taiwan is neither directly governing nor independent from the management board of directors. According to Taiwan's Corporate Law, only shareholders are qualified candidates for supervisors ${ }^{11}$ while current employees or directors are prohibited to represent in the supervisory board. Moreover, supervisors are not mandatory to be included in the board. Even though current employees or directors are prohibited to serve as supervisors, the controlling shareholders could arrange family members or the representatives of their nominal investment companies to serve the positions.

The securities regulations in Taiwan require that the shareholders with accumulative shareholding exceeding $10 \%$ of a listed company report their shareholdings. However, these shareholders for most of the cases disguise their levered control through token accounts of their family members or legal entities. And most of these token accounts are with shareholding below $10 \%$. The ownership structure is even more complicated when the controlling shareholders lever dominance through cross shareholding or pyramidal structure $^{12}$. Because that shareholding invested in the nominal investment companies is intractable, the controlling shareholder's ultimate ownership is subject to different assumptions. In this study we use alternative variables of ownership structure and board structure to capture the importance of corporate governance on market of corporate control.

\section{Development of Hypothesis}

Admati, Pfleiderer and Zechner (1994) and Huddart (1993) argue that by virtue of the

11 This restriction has been relaxed at the end of 2001. Moreover, the Taiwan Stock Exchange requires that IPO firms after January 2002 include at least two independent directors and one independent supervisor on the board.

12 The complication of ownership structure in Taiwan is not fully captured in previous studies. For example, La Porta et al. (1998) and Claessens et al. (2002) find the average voting rights of Taiwanese controlling shareholders are 18\% and $19 \%$, respectively. In contrast, the corresponding number is $27.4 \%$ in Yeh et al. (2001). 
proportional claims in accordance with ownership, the existence of a large shareholder is beneficial to all shareholders of the firms as the former has strong incentive to monitor decisions made by the firm's manager in order to reduce agency costs. Furthermore, Grossman and Hart (1988) and Shleifer and Vishny (1986) indicate that because of the free-rider problem, the large shareholder would defend shareholder interests against managerial misconduct. Gomes (2000) indicates that high cash flow investment serves as a credible commitment because minority shareholders know that if the controlling owner unexpectedly extracts high levels of private benefits when he/she still holds a substantial amount of shares, they will discount the stock price accordingly, and the majority owner's share value will be reduced. Following the line of argument, La Porta et al. (2002) and Claessens et al. (2002) identify the positive incentive of the controlling shareholder and show that the new controlling shareholder's interest is well aligned with outside shareholders' when he invests a large amount of money in the company. The manifest stake that the new controlling shareholder invests in acquisition is his cash flow rights. Therefore, our first hypothesis based on the positive incentive of the new controlling shareholder is as follows.

Hypothesis 1. The higher the cash flow possessed by the new controlling shareholder, the higher the post-change performance of the target firm.

The new controlling shareholder has the disadvantage of bearing the risk of under-diversification and the cost of monitoring, not shared by others. The question is what motivates him/her to become the new controlling shareholder? Even though the interest of the new controlling shareholder might be well aligned with the interest of minority shareholders when he/she has high level of cash flow rights, he/she could have levered control through the arrangement of pyramidal structure, cross shareholding, or dual capitalization. A deviating voting/cash flow structure allures the controlling shareholder to enhance personal interest at the expense of other shareholders. The ways of siphoning company's value include special director fees, improper related-party deals, and kickbacks. Outside minority shareholders are very unlikely to judge whether the controlling shareholder conduct malpractices that hurt their interests. This creates a leeway for the controlling shareholder to divert the firm's profit to himself. Xiang and Zhang (1996) indicate that the market for corporate control could be inefficient, as market forces tend to allocate control power to those investors who are most capable of extracting private benefits.

La Porta et al. (1999), Claessens et al. (2000) and Faccio and Lang (2002) argue that the ultimate owner has the tendency to expropriate minority interest when his voting significantly deviates from his cash flow rights. Claessens et al. (2002) show that for the 
controlling shareholders the difference between voting rights and cash flow rights is associated with a value discount, and that the discount generally increases with the size of the wedge between voting rights and cash flow rights. Therefore, our second hypothesis based on wealth expropriation of the controlling shareholder is as follows.

Hypothesis 2. The greater the extent that the controlling shareholder's control rights deviate from his cash flow rights, the lower the post-change performance of the target firm.

Gaining effective control of a corporation enables the controlling owner to determine how profits are distributed among shareholders. The most manifest approach for the controlling shareholder to be involved in target firm's decision process is to take seats on the board. With an ill intent to expropriate minority's interest, the new controller levers dominance through taking more seats of directors and supervisors. The controlling owners entrenching control through an increase of board membership are less subject to the discipline of the market of corporate control. According to the finding of Yeh, Lee and Woidtke (2001), board membership served by the controlling shareholder is negatively related to corporate value. Therefore, our third hypothesis focusing on board structure of the target firm is as follows.

Hypothesis 3. The higher the proportion of board membership in the hand of new controlling shareholder, the lower the post-change performance of the target firm

Ever since the case of Enron companies all over the world have a growing need to have activist boards- made up mainly of independent directors ${ }^{13}$. Independent outside directors are appearing on more and more boards of major US companies, and are gaining ground in Europe and in Asia countries. However, not until January 2002, the Rule required the IPO firms but not the firms that have traded in the market include 2 independent directors and 1 independent supervisor in the board. Therefore, the supervisory function of independent directors is beyond the scope of this study. Other than independent directors, is there any feasible mechanism to thwart the controlling shareholder's ambition in expropriating minority's interest?

Xiang and Zhang (1996) demonstrate that the social inefficiency from controlling shareholder's opportunism could be reduced with the emergence of a second large shareholder. Yeh, Lee and Shu (2008) indicate that the existence of a second controlling shareholder counterbalances the controlling shareholder's wealth-exploiting motivation

\footnotetext{
${ }^{13}$ Empirical evidences lend mixed support to the positive contribution of independent directors. For example, Bhagat and Black (2002) show that low-profitability firms increase the independence of their boards of directors. But there is no evidence that this strategy works. Shivdasani and Yermack (1999) find that stock price reactions to independent director appointments are significantly lower than when the general manager is involved in director selection.
} 
and serves as a good brake to prevent possible wealth expropriation. Given that the second controlling shareholder provides the function of check and balance, our fourth hypothesis is as follows.

Hypothesis 4. The higher the proportion of board membership controlled by the second controlling shareholder, the higher the post-change performance of the target firm.

Note that the aforementioned hypotheses mainly come from the interest-alignment hypothesis and wealth-exploitation hypothesis, well documented in La Porta et al. (2002), Claessens et al. (2002) and received some supporting evidences in different scenarios. However, so far as we know applying the notion of corporate governance on the case of control change has never been empirically examined. Our investigation is interesting because that there are two competitive threads of thinking to predict the post-change performance. The first one is corporate governance variables; boil down in our case as the ownership structure (hypothesis 1 and 2) and the board structure (hypothesis 3 and 4). The alternative argument comes from the market of corporate control, which predicts an improvement of the post-change performance suffice the market is efficient.

\section{Data and Samples Description}

\subsection{Data and Variable Definition}

The data is hand collected for the Taiwanese listed firms that have changed in control and remained listed for at least 3 accounting years after the change. Change in control is defined as when the joint condition that the controlling shareholder is replaced and that this new controlling shareholder controls more than $20 \%$ voting rights or more than half of the seats on the board is satisfied. The new controlling shareholder obtains his dominance in the targets through open market purchases of shares or negotiation with the previous controlling shareholders. Though in lack of detailed information to show the exact timing when the controlling shareholders acquire the stakes, the practical knowledge indicates that the controlling shareholders would purchase block shares approximating the timing of replacing directors and supervisors, taking place on the board of stockholders on April through June for every three year. Of course leveling the schedule of share purchases would reduce the market impact due to the negative demand curve for the stock and would length the purchasing schedule. Since listing itself is deemed an asset to the acquirer, all listed companies remained listed after change in control. Thus, our sample is free from the possible survivorship bias and provides a splendid forum to examine the influence of the change in corporate and firm performance. Since three-year performance measures of the target firms are needed for inter-temporal 
comparisons before and after the changes, our sampling period is right-censored in $1999^{14}$. In total there are 46 effective samples from 1991 through 1999.

According to the concept of ultimate control proposed by La Porta et al. (1999), we trace the voting rights, cash flow rights and board seats held by the controlling shareholder from the company prospectus of the firms that change in control. Those who have the dominant voting rights are recognized as the controlling shareholders. Most of the controlling shareholder pertains to a family whose membership is related through blood or marriage. This data of the shareholdings of managers, directorates, supervisors, and their relatives are hand-collected from company annual reports or prospects. Since the Rules require the names of the affiliated persons ${ }^{15}$ of large shareholders, directors, and supervisors through blood or marriage reported in company financial report, we are able to trace the ownership structure and calculate the voting rights and cash flow rights of the controlling shareholders.

The voting rights of the controlling family are the summed shareholdings directly controlled by family-affiliated persons and the shareholdings of institutions that is in turn controlled by these family-affiliated persons. The ultimate voting rights equal the sum of direct and indirect voting rights belonging to the same controlling body. Direct voting rights refer to the shares registered under the names of the controlling shareholder and his affiliated individuals. Indirect voting rights refer to the shares registered under other companies or institutions controlled by the same controlling shareholder. According to Claessens et al. (2000), when existing multiple control chains the voting rights are the summed voting rights along each chain with weakest linkage among all layers of holding.

The cash flow rights along each chain are the products of all ownership in the intermediate companies along that chain. The total cash flow rights are equal to the sum of all cash flow rights from all ownership chains. For example, suppose family A owns $30 \%$ of company B, which in turn owns $20 \%$ of company C. In addition family A owns $20 \%$ of company D directly, which in turn owns $10 \%$ of company $\mathrm{C}$ (This constitutes the second control chain of family A over company C). Family A's control rights over company $\mathrm{C}$ are $\operatorname{Min}(30 \%, 20 \%)+\operatorname{Min}(20 \%, 10 \%)=30 \%$, while the cash flow rights generated from company $\mathrm{C}$ are $30 \% * 20 \%+20 \% * 10 \%=8 \%$. Thus family A possesses dominant power in affecting company C's operation but only shares $8 \%$ of company $\mathrm{C}$ 's profits, dividends and the loss due to agency misconduct.

One problem in calculating cash flow rights is that the shareholding of nominal

\footnotetext{
14 The three-year performance measures included the performance measures in the exact year of change in control, and the performance measures for the next two following years.

15 The affiliated person refers to spouse, parents, children, siblings, mother-in-law, father-in-law, sons and daughters-in-law, brothers and sisters-in-law.
} 
investment companies or equivalent entities along the control chain cannot be explicitly identified $^{16}$. An easy way out is to assume that the controlling shareholder invests $50 \%$ of the shareholding of these nominal companies, and then to conduct a sensitivity analysis by varying the invested shareholding from $0 \%$ through $100 \%$.

The possible relationship of board members (directors and supervisors), their identifiable relatives, and legal representatives from other companies or entities that in turn are controlled by them is explicitly identified. This identifiable relationship serves as the basis to determine the possible affiliation of the controlling shareholder. If the controlling shareholder happens to be a widely held corporation, the delegates appointed to the board are regarded as affiliates of the controlling shareholder.

The second controlling shareholder is defined as the one who hold shareholding more than $5 \%$ while is not affiliated with the controlling shareholders through blood/marriage tie nor is a representative of an investment company of the controlling shareholder. The second controlling shareholder when existence tends to be the second largest family, an insurance company, or a governmental institution. In our investigated cases, there are 26 acquired firms are with the existence of the second controlling shareholder. The proportion of directors or supervisors controlled by the second controlling shareholder serves as the proxy variable that counterbalances possible wealth exploitation conducted by the controlling shareholder.

The performance measures used in this study include return on equity (ROE), return on assets (ROA), return on operating cash flow (OCF) and earnings per share (EPS). ROE is defined as a firm's net income divided by the average of its equity book value. ROA is defined as a firm's net income by adding after-tax interest and then divided by average assets value. OCF is defined as a firm's operating cash flow divided by average assets value. Operating cash flow is earnings before interest and taxes (EBIT) by adding depreciation and subtracting taxes. EPS is defined as a firm's net income dividend by the outstanding shares with an adjustment of diluting effect of stock dividend ${ }^{17}$. In order to control industry effect ${ }^{18}$, the median measures in the same industry are firstly subtracted from the corresponding measures (ROE, ROA, OCF, EPS, and EBIT) of our investigated targets before being included in the regression analysis. Specifically, $\mathrm{ROE}_{3}^{\mathrm{A}}$ refers to the 3 -year ROE of the firm after changing control minus the median ROE of firms in the same industry in a cohort year. Moreover, in order to control inter-temporal change of a

\footnotetext{
${ }^{16}$ When the nominal investment companies and entities are private companies, they are not subject to disclosure requirements.

17 It is not uncommon for listed firms in Taiwan issue stock dividends and that might dilute the reported EPS. We have included the issue of the diluting effect into considerations in calculating EPS.

${ }^{18}$ There are 20 industry categories from the TSEC: cement, food, plastic, textile and fiber, electric and machine engineering, wire and cable, chemical, glass and ceramic, paper, steel, rubber, computer, construction, transport, hotel, bank and insurance, trade, department stores, and miscellaneous item.
} 
target firm, we also take first difference of the industry-adjusted measures. For example, $\mathrm{ROE}_{3}^{\mathrm{A}}-\mathrm{ROE}_{-3}^{\mathrm{A}}$ refers to inter-temporal difference between 3-year industry-adjusted ROE after control change and 3-year industry-adjusted ROE before control change. We also use dummy variables to control the effects that general manager is replaced after acquisition or not (Dummy Manager Change), that the controlling shareholder simultaneously serves as the chairman and general manager in the target firm or not (Dummy Participation), and that the target firm is in the same industry as the acquiring firm or not (Dummy Related).

\subsection{Summary Statistics}

The effective sample firms have to meet the joint condition that the controlling shareholder is replaced and that the new controlling shareholder obtains more than $20 \%$ voting rights or controls more than half of board membership. The reason that there were only 46 cases in a decade is that takeovers are somewhat subdued from happening in most Asian countries where the ownership of large publicly traded firms is generally controlled on the hands of families (Claessens et al., 2000) .Moreover, in our sampling period the Rules stipulate that acquirers need to file application and get permission by the regulative entity before launching a takeover. The sample distribution summarized in Table 1 indicates that the cases are not specifically tilted toward a certain year. The cases also cover 12 industries out of the 20 2-digit industrial classification in Taiwan, which warrants the use of industry adjusted performance measures. Therefore, our sample is less likely to incur selection bias or to jeopardize the empirical results.

Table 1. Sample Distribution

This table reports the sample distribution breakdown by year, industry, and type of block purchase, respectively.

\begin{tabular}{|l|l|l|l|l|l|}
\hline Year & No. & Industry & No. & $\begin{array}{l}\text { Type of Block } \\
\text { Purchase }\end{array}$ & No. \\
\hline 1991 & 3 & Electric & 13 & Open Market Purchase & 37 \\
\hline 1992 & 1 & Textile & 9 & Proxy Fight & 9 \\
\hline 1993 & 0 & Food & 4 & & \\
\hline 1994 & 10 & Construction & 4 & & \\
\hline 1995 & 5 & Finance & 4 & & \\
\hline 1996 & 9 & Iron and Steel & 3 & & \\
\hline 1997 & 8 & Rubber & 2 & & \\
\hline 1998 & 4 & Glasses and Ceramic & 2 & & \\
\hline 1999 & 6 & Electric Machinery & 2 & & \\
\hline & & Plastic & 1 & & \\
\hline & & General Merchandise & 1 & & \\
\hline & & Miscellaneous & 1 & & \\
\hline total & 46 & & 46 & & \\
\hline
\end{tabular}


The results in Table 2 show that after control change, the new controlling shareholders on average possesses $22.44 \%$ voting rights (the median of $14.66 \%$ ) and $6.35 \%$ cash flow rights ( $4.70 \%$ for the median). The average deviation of voting from cash flow rights is $16.09 \%$. Even excluding the cases of proxy fight ${ }^{19}$ from the sample, the discrepancy is still $8.93 \%$.

The controlling shareholders exert power and lever dominance in the board of the target firms. On average $66.34 \%$ of directors and $61.96 \%$ of supervisors are represented by the controlling shareholders. There are about $80 \%$ of the cases that more than half of the directors are represented by the controlling shareholders. The second controlling shareholders, on average, hold $13.82 \%$ and $12.53 \%$ of the directorates and supervisors of the target firms, respectively. Moreover, the result from the participating-management dummy illustrates that in more than half of these cases $(52.17 \%)$ the controlling shareholders do involve in management practices by serving both as the chairman of the board and the general manager of the target firm.

Prior to change in control the three-year average ROE of the target firms is $-3.79 \%$. This implies that the takeover targets tend to be poor performers followed by market discipline of corporate control. However, replacement itself lends no credence to warrant improvement of performance. In fact, the post-change performance measures were even worst than their pre-change level..

Other control variables, such as asset value ${ }^{20}$, debt ratio ${ }^{21}$, R\&D expenditure, and advertising expenditures ${ }^{22}$, wildly cited to have influence on firm's performance (Morck, Shleifer and Vishny, 1988; McConeel and Servaes, 1990; Craswell, Taylor and Saywell, 1997) did not show significant differences between their pre- and post-change levels ${ }^{23}$.

\footnotetext{
${ }^{19}$ In the 9 cases involving a proxy fight, the controlling shareholders obtained voting rights by purchasing proxies, however, they did not have cash flow rights in the target firms. Launching contests through purchasing proxies has been forbidden since 1997.

20 According to Morck et al. (1988), it is easier to own a large portion of a small firm because of smaller outlay required. Controlling for size avoids the possibility that large board stakes simply proxy small firm size. Also, size could be correlated with intangible assets that enhance firm's performance.

${ }^{21}$ Debt ratio has two possible effects on firm's value. According to Morck et al. (1988) and Craswell et al (1997), debt ratio captures the value of tax shields as to improve corporate performance, while excessive use of debt induces higher expected cost of financial distress as to lower firm's performance.

${ }_{22}$ According to Mock et al. (1988), McConell and Servaes (1990), this variable is added because it reflects the expense to increase book value of a firm's intangible assets. McConnell and Muscarella (1985), Chan, Martin and Kensinger (1990) found evidence in support of the hypothesis that investment affects corporate value. Crutchley and Hansen (1989); Jensen, Solberg and Zorn (1992) use this variable to measure the further growth opportunity of a firm.

${ }^{23}$ At a first glance, it is a little strange because that incumbent with high debt ratio is less likely to be the takeover targets. We further segregate the sample into financial and non-financial firms. The three-year averaged debt ratio for the 4 financial cases is $91.89 \%$ before the control change. The corresponding industry average in the 1991-1999 sampling period falls in the range between $91.65 \%$ and $94.66 \%$. The three-year averaged debt ratio for the 42 non-financial firms is $48.82 \%$ before the control change. The industry average falls in the range between $40 \%$ and $48 \%$. Therefore, the averaged debt ratio for our sampling firms is not significantly different from the market average
} 
Table 2. Basic Statistics of Variables

This table summarizes the basic statistics for the corporate-governance (CG) variables and other variables of interest from a sample of acquisitions beginning from 1991 and ending 1999. There are 46 effective cases in which the acquiring firms or individuals obtained control right and the top managers of the target firms are replaced after change in control. The cash flow rights of the ultimate control shareholder, according to La Porta et al. (1999), are the sum of the products from the ownership stakes along the chains of ownership. The control right is the sum of the weakest links along the chains of ownership. Dummy Participation is assigned the value 1 when the controlling shareholder in person is in charge of managing the target firm and 0 otherwise. The proportion of director seats (supervisors) that serve the controlling (second largest) shareholder is reported accordingly. The 3-year averaged asset value in natural logarithm, debt ratio, $R \& D$ expenditure ratio, advertisement fee ratio, return on equity (ROE), return on operating cash flow (OCF), earnings per share (EPS), and return on assets (ROA) before and after acquisition activities are reported and the differences between the value before and after acquisition are calculated. For example, the 3-year averaged asset value in natural logarithm before acquisition is denoted as ln (asset)-3 and the one after acquisition is denoted as $\ln$ (asset) 3 ROE is the net income of the target firm divided by its net worth. OCF is a firm's earnings before interest and taxes (EBIT) plus depreciation and minus taxes. OCF is defined as OCF divided by the total assets value. Tobin's $Q$ is defined as a firm's market asset value divided by book asset value.

\begin{tabular}{|c|c|c|c|c|c|}
\hline Variable & Mean & S.D. & Q1 & Median & Q3 \\
\hline Voting rights of the Controlling Shareholder (\%) & 22.44 & 19.5390 & 8.65 & 14.66 & 29.39 \\
\hline Cash flow rights of the Controlling Shareholder (\%) & 6.35 & 5.5840 & 2.91 & 4.70 & 6.52 \\
\hline Voting rights - Cash flow rights (\%) & 16.09 & 19.7741 & 3.91 & 6.91 & 17.46 \\
\hline Cash flow rights / Voting rights & 0.4284 & 0.2747 & 0.1613 & 0.5000 & 0.5360 \\
\hline Dummy Participation & 0.5217 & 0.5050 & 0 & 1 & 1 \\
\hline $\begin{array}{l}\text { Proportion of Directors Represented by the Controlling } \\
\text { Shareholder }\end{array}$ & 0.6634 & 0.1913 & 0.5330 & 0.6095 & 0.7780 \\
\hline $\begin{array}{l}\text { Proportion of Supervisors Represented by the Controlling } \\
\text { Shareholder }\end{array}$ & 0.6196 & 0.3425 & 0.3330 & 0.6335 & 1 \\
\hline $\begin{array}{l}\text { Proportion of Directors Represented by the Second } \\
\text { controlling shareholder }\end{array}$ & 0.1382 & 0.1527 & 0 & 0.1145 & 0.2220 \\
\hline $\begin{array}{l}\text { Proportion of Supervisors Represented by the Second } \\
\text { controlling shareholder }\end{array}$ & 0.1253 & 0.1894 & 0 & 0 & 0.3330 \\
\hline Ln (assets) ${ }_{3}$ & 15.9151 & 1.2170 & 14.9591 & 15.6693 & 16.5929 \\
\hline Ln (assets) $)_{-3}$ & 15.4217 & 1.2304 & 14.4223 & 15.1793 & 15.9897 \\
\hline $\operatorname{Ln}(\text { assets })_{3}-\operatorname{Ln}(\text { assets })_{-3}$ & 0.4934 & 0.4932 & 0.1237 & 0.3669 & 0.8104 \\
\hline Debt Ratio $_{3}(\%)$ & 57.75 & 17.7058 & 42.50 & 53.42 & 70.57 \\
\hline
\end{tabular}




\begin{tabular}{|c|c|c|c|c|c|}
\hline Debt Ratio $_{-3}(\%)$ & 52.57 & 20.6726 & 37.83 & 48.89 & 66.32 \\
\hline 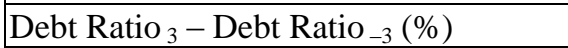 & 5.18 & 12.5890 & -4.25 & 6.37 & 11.86 \\
\hline R\&D Ratio $3(\%)$ & 0.87 & 2.3804 & 0.00 & 0.33 & 0.77 \\
\hline $\operatorname{R} \& D$ Ratio $_{-3}(\%)$ & 0.89 & 1.5635 & 0.01 & 0.37 & 0.99 \\
\hline R\&D Ratio $_{3}-$ R\&D Ratio $_{-3}(\%)$ & -0.01 & 1.1761 & -0.29 & -0.01 & 0.00 \\
\hline Advertisement $_{3}(\%)$ & 0.0101 & 0.0171 & 0.0000 & 0.0014 & 0.0117 \\
\hline Advertisement $_{-3}(\%)$ & 0.0094 & 0.0170 & 0.0001 & 0.0013 & 0.0110 \\
\hline Advertisement $_{3}$ - Advertisement $_{-3}(\%)$ & 0.0007 & 0.0167 & -0.0021 & -0.0001 & 0.0008 \\
\hline $\mathrm{ROE}_{3}(\%)$ & -10.01 & 26.7505 & -18.18 & -0.53 & 6.03 \\
\hline $\operatorname{ROE}_{-3}(\%)$ & -3.79 & 19.1828 & -8.35 & 0.52 & 5.64 \\
\hline $\mathrm{ROE}_{3,}, \mathrm{ROE}_{-3}(\%)$ & -6.22 & 24.7439 & -15.38 & -5.07 & 4.85 \\
\hline $\mathrm{OCF}_{3}(\%)$ & 2.23 & 4.0419 & 0.57 & 3.40 & 4.81 \\
\hline $\mathrm{OCF}_{-3}(\%)$ & 3.31 & 2.9606 & 2.03 & 3.21 & 5.43 \\
\hline $\mathrm{OCF}_{3}(\%)-\mathrm{OCF}_{-3}(\%)$ & -1.08 & 4.5002 & -3.02 & -0.84 & 1.74 \\
\hline $\mathrm{EPS}_{3}(\$)$ & -0.51 & 2.0199 & -1.73 & -0.003 & 0.77 \\
\hline $\mathrm{EPS}_{-3}(\$)$ & -0.13 & 1.9016 & -0.91 & 0.03 & 0.86 \\
\hline $\mathrm{EPS}_{3}(\$)-\mathrm{EPS}_{-3}(\$)$ & -0.39 & 2.6236 & -1.80 & -0.54 & 0.53 \\
\hline $\mathrm{ROA}_{3}(\%)$ & -1.14 & 7.1936 & -4.80 & 1.03 & 3.89 \\
\hline $\mathrm{ROA}_{-3}(\%)$ & 1.11 & 5.3952 & -0.90 & 1.03 & 3.86 \\
\hline $\operatorname{ROA}_{3}(\%)-\mathrm{ROA}_{-3}(\%)$ & -2.25 & 8.4564 & -4.62 & -1.46 & 1.86 \\
\hline
\end{tabular}

\subsection{Industry-adjusted Performance}

The relation between performance and change in control might be industry specific. As shown in Table 1 our cases covering 12 out of 20 industries warrant the use of industry adjusted performance measures. The median performance measure for firms in the same industry is subtracted from the target firm's corresponding measure. Table 3 summarizes the inter-temporal comparisons of the industry-adjusted performance measures for these target firms.

The results show that the target firms performed inferior to their industry benchmarks both for the pre- and post-change performance measures, and most of them are significant at $1 \%$ level. The picture further evidences that the targets of takeover tend to be poor performers whose post-change performance measures were even worse than their pre-change level. The result also contradicts the dictum of the synergy hypothesis.

An unreported result shows that there were only 10 out of the 46 cases that the general managers were retained after change in control. There were 25 cases that the general managers were replaced right after acquisitions, 7 cases of managerial replacement in one year, and 4 cases of managerial replacement in 2 years but beyond 1 year after the change 
in control. The statistics implies that the new controlling shareholder tends to discipline and replace the poor-performing managers. However, replacement itself is insufficient to guarantee performance improvement. We further investigate whether the managerial replacement is related to firm's performance. The results show that firms replacing general managers show improvement on EPS and ROA, albeit insignificant. Those firms that retained general managers performed even worse than their pre-change level. As predicted by Xiang and Zhang (1995), the corporate market might be inefficient so as to allocate the control power to the ones that are most capable of extracting private benefits.

Given that the controlling shareholders effectively control the board and are deeply involved in the affairs of the target firms, as evidenced from Table 2, the post-change performance of the target firms that might be related to the corporate governance structure is a critical issue. We will examine this issue in the next section.

Table 3. Difference Test in Industry-Adjusted Pre- and Post-change Performance

This table reports on the tests of differences in industry-adjusted performance measures before and after acquisition activities. The variable definitions are in Table 1. The industry-adjusted performance measure is obtained by subtracting the median of firms in the same industry as the target firm from the corresponding performance measure. The superscript " $A$ " indicates "industry-adjusted", and the subscript 3 and -3 indicate 3 years of post- and pre-change in control, respectively. ***, **, and * denote the significance level of $1 \%, 5 \%$, and $10 \%$, respectively.

\begin{tabular}{|l|c|c|c|}
\hline Performance Measure & Mean & S.D. & t-statistic \\
\hline $\mathrm{ROE}_{3}^{\mathrm{A}}(\%)$ & -17.39 & 26.64 & $-4.427 * * *$ \\
\hline $\mathrm{ROE}_{-3}^{\mathrm{A}}(\%)$ & -14.29 & 19.69 & $-4.922 * * *$ \\
\hline $\mathrm{ROE}_{3}^{\mathrm{A}}-\mathrm{ROE}_{-3}^{\mathrm{A}}(\%)$ & -3.10 & 24.47 & -0.859 \\
\hline $\mathrm{OCF}_{3}^{\mathrm{A}}(\%)$ & -1.06 & 3.64 & $-1.977 *$ \\
\hline $\mathrm{OCF}_{-3}^{\mathrm{A}}(\%)$ & -1.70 & 4.27 & $-2.699 * *$ \\
\hline $\mathrm{OCF}_{3}{ }_{3}-\mathrm{OCF}_{-3}^{\mathrm{A}}(\%)$ & -0.64 & 4.49 & -0.965 \\
\hline $\mathrm{EPS}_{3}^{\mathrm{A}}(\%)$ & -1.67 & 2.01 & $-5.615^{* * *}$ \\
\hline $\mathrm{EPS}_{-3}^{\mathrm{A}}(\%)$ & -1.76 & 2.03 & $-5.887 * * *$ \\
\hline $\mathrm{EPS}_{3}^{\mathrm{A}}-\mathrm{EPS}_{-3}^{\mathrm{A}}(\%)$ & 0.09 & 2.62 & 0.242 \\
\hline $\mathrm{ROA}_{3}^{\mathrm{A}}(\%)$ & -5.85 & 7.60 & $-5.226 * * *$ \\
\hline $\mathrm{ROA}_{-3}^{\mathrm{A}}(\%)$ & -5.19 & 6.27 & $-5.615^{* * *}$ \\
\hline $\mathrm{ROA}_{3}^{\mathrm{A}}-\mathrm{ROA}_{-3}^{\mathrm{A}}(\%)$ & -0.66 & 8.57 & -0.525 \\
\hline
\end{tabular}


5. Results

\subsection{Corporate Governance and Acquisition Performance}

To examine whether controlling shareholder's involvement affects post-change performance, we regress the post-change industry-adjusted $\mathrm{ROE}\left(\mathrm{ROE}_{3}^{\mathrm{A}}\right)$ and the inter-temporal difference of industry-adjusted $\mathrm{ROE}\left(\mathrm{ROE}_{3}^{\mathrm{A}} \mathrm{ROE}_{-3}^{\mathrm{A}}\right.$ ) on the corporate governance and other related variables. Our performance measures are industry adjusted and inter-temporal industry adjusted as to accommodate systematic changes. Therefore, the results would not be affected by any change in reporting and accounting standard. The results are summarized in panel A and B of Table 4, respectively. Note that the control variables, namely firm's assets, debt ratio, R\&D ratio, and advertisement, are coherently treated with the dependent variables, i.e. the control variables are industry-adjusted in panel $\mathrm{A}$ when the dependent variable is $\mathrm{ROE}_{3}^{\mathrm{A}}$, and are inter-temporal and industry-adjusted in panel $\mathrm{B}$ when the dependent variable is $\mathrm{ROE}^{\mathrm{A}}{ }_{3}-\mathrm{ROE}^{\mathrm{A}}{ }_{-3}$. Also note that the yearly fixed effect is controlled in regressions while not reported for brevity.

The results in panel A show that controlling shareholder's cash flow rights are positively related to post-change ROE of the firms than change in control, and are significant in three out of four regressions. For example, the result in the third regression of panel A indicates that one percentage increase of controlling shareholder's cash flow rights leads to $1.40 \%$ increase in post-change industry-adjusted ROE. The regression coefficients of the inter-temporal and industry-adjusted ROE on cash flow rights are also positive and marginally significant (panel B). This result basically supports our first hypothesis that the controlling shareholder's interest is aligned with outside shareholders' when he/she has high cash flow rights on hand. His positive incentive contributes to the target's performance.

La Porta et al. (1999), Claessens et al. (2000) and Faccio and Lang (2002) predict that controlling shareholder might have a tendency of wealth expropriation and hurt the firm's performance when his voting rights significantly deviate from cash flow rights. However, our empirical results lend little support to this argument. We will further discuss this issue latter.

Another manifest approach for the controlling shareholder to expropriate wealth is through the control of board membership. The results show that the regression coefficient of the proportion of directors represented by the controlling shareholder is -0.4182 in panel A, and -0.4268 in panel B, both are significant at $5 \%$ level. The result supports the third hypothesis that the proportion of board membership pertaining to the new controlling shareholder is detrimental to post-change performance of the target firms. The 
proportion of supervisors represented by the controlling shareholder is also negatively related to target's performance measure, albeit less significant. Moreover, involvement of the controlling shareholder in management practices connotes a negative value to post-change performance.

A counterbalancing power to prevent the wealth exploitation by the controlling shareholder originates from the second controlling shareholder. The proportion of directors obtained by the second controlling shareholder is positively related to post-change industry-adjusted ROE (panel A) and the inter-temporal industry-adjusted ROE (panel B), both are significant at the $1 \%$ level. Specifically, one percent increase of the proportion of directors controlled by the second controlling shareholder results in $0.6085 \%$ increase in the industry-adjusted $\mathrm{ROE}$ and $0.5566 \%$ increase in the inter-temporal difference of industry-adjusted ROE. The increase in target's performance is not only statistically significant but also economically valuable. For example, a target firm with a board composed of 10 directors would imply 6\% increase in its ROE if one more director represented by the second controlling shareholder. Moreover, supervisors designated to enhance sound business practices is also positively related to the target's industry-adjusted ROE, albeit less significant. The overall picture supports our forth hypothesis that the second controlling shareholder provides positive surveillance function to ward off the controlling shareholder's wealth exploitation.

Note that the separation of cash flow rights and voting rights, the main cause for agency costs that hurt firm performance (La Porta et al, 2002; Claessens et al.,2002; Bebchuk, Kraakman and Triantis, 2000) is insignificant to affect the post-change performance. A possible explanation is that board structure variables subject to fewer measurement errors than the voting/cash deviation. For example, the ultimate controlling holders might be supported by the other friendly shareholders or launch a proxy fight as to control more seats on the board than their merits. This is the case of control/cash-flow deviation while not the case of voting/cash-flow deviation. Any corporate momentous decisions have to be ultimately reviewed and securitized by the board. Therefore, the board structure rather than the voting/cash-flow deviation manifests the true structure of control power over a firm. Note that for brevity reason we do not report the result of yearly fixed effect that does provide explanatory power on dependent variables. .

\section{Table 4. Regression of ROE on Corporate Governance Variables}

The dependent variable in panel A (ROEA3) is the 3-year averaged industry-adjusted ROE for target firm post change in control. The dependent variable in panel B (ROEA3 - ROEA-3) is the inter-temporal difference for the post-3-year and pre-3-year averaged industry-adjusted ROE of the target firm. The dummy Manager Change is an assigned 
value of 1 if the manager of the target firm is changed post change in control, and 0 otherwise. The dummy Participation is assigned the value of 1 when the controlling shareholder in person is in charge of managing the target firm, and 0 otherwise. The dummy Related is assigned a value of 1 if the target firm is from the same industry as the acquiring firm, and 0 otherwise. The other variables are defined in Table 1. In each cell the regression coefficient and t-statistics in parentheses are provided accordingly. $* * *, * *$, and $*$ denote the significance level of $1 \%, 5 \%$, and $10 \%$, respectively.

\begin{tabular}{|c|c|c|c|c|c|c|c|c|}
\hline \multirow{3}{*}{$\begin{array}{l}\text { Independent Variable } \\
\text { Intercept }\end{array}$} & \multicolumn{4}{|c|}{ Panel A: Dependent Variable: $\mathrm{ROE}_{3}^{\mathrm{A}}$} & \multicolumn{4}{|c|}{$\begin{array}{c}\text { Panel B: Dependent Variable }\left(\mathrm{ROE}_{3}^{\mathrm{A}}\right. \\
\left.-\mathrm{ROE}_{-3}^{\mathrm{A}}\right)\end{array}$} \\
\hline & 16.9854 & -2.3185 & -20.0958 & -11.2818 & 19.4269 & -4.0198 & -16.8333 & -9.8707 \\
\hline & $(1.402)$ & $(-0.257)$ & $\begin{array}{c}(-2.566)^{*} \\
*\end{array}$ & $(-1.445)$ & $(1.388)$ & $(-0.407)$ & $(-2.116) *$ & $(-1.250)$ \\
\hline \multirow{2}{*}{$\begin{array}{l}\text { Proportion of Directors Represented by the } \\
\text { Controlling Shareholder }\end{array}$} & -0.4182 & & & & -0.4268 & & & \\
\hline & $\begin{array}{c}(-2.401)^{*} \\
*\end{array}$ & & & & $\begin{array}{c}(-2.042)^{*} \\
*\end{array}$ & & & \\
\hline \multirow{2}{*}{\begin{tabular}{|l} 
Proportion of Supervisors Represented by the \\
Controlling Shareholder \\
\end{tabular}} & & -0.0868 & & & & -0.0244 & & \\
\hline & & $(-0.887)$ & & & & $(-0.229)$ & & \\
\hline \multirow{2}{*}{$\begin{array}{l}\text { Proportion of Directors Represented by the } \\
\text { Second controlling shareholder }\end{array}$} & & & 0.6085 & & & & 0.5566 & \\
\hline & & & $\begin{array}{c}(3.052)^{* *} \\
*\end{array}$ & & & & $(2.526)^{* *}$ & \\
\hline \multirow{2}{*}{$\begin{array}{l}\text { Proportion of Supervisors Represented by the } \\
\text { Second controlling shareholder } \\
\end{array}$} & & & & 0.2693 & & & & 0.2277 \\
\hline & & & & $(1.502)$ & & & & $(1.183)$ \\
\hline \multirow{2}{*}{ Cash flow rights (\%) } & 1.1222 & 0.9315 & 1.3964 & 1.2497 & 1.0842 & 0.9614 & 1.1789 & 1.1215 \\
\hline & $(1.886)^{*}$ & $(1.465)$ & $(2.416) * *$ & $(1.945)^{*}$ & $(1.493)$ & $(1.309)$ & $(1.667)$ & $(1.441)$ \\
\hline \multirow{2}{*}{ Voting rights - Cash flow rights (\%) } & 0.0277 & 0.0417 & 0.0646 & 0.0325 & -0.0311 & 0.0099 & 0.0232 & 0.0063 \\
\hline & $(0.174)$ & $(0.249)$ & $(0.428)$ & $(0.197)$ & $(-0.183)$ & $(0.054)$ & $(0.141)$ & $(0.036)$ \\
\hline \multirow{2}{*}{ Dummy Manager Change } & 7.8214 & 5.5760 & 8.4874 & 6.8217 & 6.5713 & 4.4114 & 7.356 & 4.9119 \\
\hline & $(1.204)$ & $(0.805)$ & $(1.367)$ & $(0.995)$ & $(0.930)$ & \begin{tabular}{|l|}
$(0.589)$ \\
\end{tabular} & $(1.071)$ & \begin{tabular}{|l}
$(0.673)$ \\
\end{tabular} \\
\hline \multirow{2}{*}{ Dummy Participation } & -4.3709 & -6.684 & -3.1746 & -5.8580 & -10.6100 & \begin{tabular}{|l|}
-11.1614 \\
\end{tabular} & -7.8666 & -10.8973 \\
\hline & $(-0.710)$ & $(-1.033)$ & $(-0.534)$ & $(-0.914)$ & $(-1.197)$ & $(-1.190)$ & $(-0.901)$ & $(-1.186)$ \\
\hline \multirow{2}{*}{ Dummy Related } & 5.9951 & 5.6783 & 3.5287 & 4.2662 & 12.2695 & 11.3595 & 8.5155 & 9.8000 \\
\hline & $(0.908)$ & $(0.802)$ & $(0.551)$ & $(0.601)$ & $(1.673)$ & $(1.455)$ & $(1.177)$ & $(1.265)$ \\
\hline \multirow{2}{*}{$\ln$ (assets) } & 6.0902 & 6.9842 & 6.8256 & 8.2039 & 5.2407 & -0.0653 & 1.7195 & 0.7067 \\
\hline & $(1.819)^{*}$ & $(1.949)^{*}$ & $(2.158) * *$ & $(2.367)^{* *}$ & $(0.677)$ & $(-0.008)$ & $(0.243)$ & $(0.094)$ \\
\hline \multirow[b]{2}{*}{ Debt Ratio } & -0.7115 & -0.7299 & -0.7232 & -0.7588 & -0.1693 & -0.3829 & -0.3833 & -0.3624 \\
\hline & $\begin{array}{c}(-3.797)^{*} \\
* *\end{array}$ & $\begin{array}{c}(-3.615)^{*} \\
* *\end{array}$ & $\begin{array}{c}(-4.037)^{*} \\
* *\end{array}$ & $\begin{array}{c}(-3.884)^{*} \\
* *\end{array}$ & $(-0.448)$ & $(-0.999)$ & $(-1.086)$ & $(-0.963)$ \\
\hline \multirow{2}{*}{ R\&D Ratio } & -0.7408 & -0.3055 & -0.0264 & -0.4162 & -3.6358 & -1.7074 & -1.2814 & -1.4463 \\
\hline & $(-0.553)$ & $(-0.210)$ & $(-0.020)$ & $(-0.296)$ & $(-1.211)$ & $(-0.567)$ & $(-0.461)$ & $(-0.488)$ \\
\hline \multirow{2}{*}{ Advertisement } & $\begin{array}{c}-371.887 \\
1 \\
\end{array}$ & $\begin{array}{c}-461.207 \\
6 \\
\end{array}$ & \begin{tabular}{|c|}
-482.207 \\
6 \\
\end{tabular} & $\begin{array}{c}-462.758 \\
3\end{array}$ & $\begin{array}{c}-413.523 \\
4\end{array}$ & $\begin{array}{c}-399.009 \\
0 \\
\end{array}$ & $\begin{array}{c}-438.592 \\
6 \\
\end{array}$ & $\begin{array}{c}-441.132 \\
0\end{array}$ \\
\hline & $(-1.863)^{*}$ & $\begin{array}{c}(-2.215)^{*} \\
*\end{array}$ & $\begin{array}{c}(-2.578)^{*} \\
*\end{array}$ & $\begin{array}{c}(-2.260) * \\
*\end{array}$ & $(-1.538)$ & $(-1.392)$ & $(-1.674)$ & $(-1.575)$ \\
\hline Adjusted $\mathrm{R}^{2}$ & $47.44 \%$ & $38.98 \%$ & $52.11 \%$ & $41.34 \%$ & $25.13 \%$ & $15.35 \%$ & $29.59 \%$ & $18.64 \%$ \\
\hline
\end{tabular}

In table 5 the return of post-change industry-adjusted operating cash flow ( $\mathrm{OFC}_{3}^{\mathrm{A}}$ ) and their intertemporal difference $\left(\mathrm{OCF}_{3}^{\mathrm{A}}-\mathrm{OCF}_{-3}^{\mathrm{A}}\right)$ were regressed on the corporate governance and other control variables. The results are summarized in panel A and B, respectively. 
The results are basically similar to the evidence in Table 4. The controlling shareholder's cash flow rights are positive but less significant in affecting industry-adjusted return on post-change industry-adjusted OCF. The regression coefficient of the discrepancy between controlling shareholder's cash and voting rights is negative, which is as predicted while less significant. Therefore, the results lend little credence to the first two hypotheses.

The industry-adjusted post-change operating cash flow is negatively related to the proportion of directors represented by the controlling shareholder, while positively related to that the proportion of directors controlled by the second controlling shareholder. Specifically, one percentage increase of the proportion of directors represented by the controlling shareholder results in $0.0565 \%$ decrease of the industry-adjusted OCF of the firm that change in control. The existence of the second controlling shareholder provides surveillance function in that one percentage increase of the proportion of directors controlled by him results in $0.0996 \%$ increase of the industry-adjusted OCF (panel A). Similarly, one percent increase of the proportion of directors represented by the controlling shareholder results in $0.0453 \%$ decrease of the inter-temporal difference of the industry-adjusted OCF, and one percentage increase of directors represented by the second controlling shareholder results in $0.1196 \%$ increase of the intertemporal difference of the industry-adjusted OCF of the target firm (panel B). As a whole, both the evidences from ROE and OCF indicate that when the controlling shareholder achieves predominance over the board structure without proper surveillance from the second controlling shareholder, the post-change performance of the target firm is destined to decline.

Besides the corporate governance variables, we find that the debt ratio is negatively related to the industry-adjusted performance measures. Moreover, the advertisement ratio is negatively related to the industry-adjusted post-change ROE (in panel A of Table 4) and the inter-temporal difference of advertisement ratio is negatively related to their inter-temporal difference of the industry-adjusted OCF (in panel B of table 5).

Table 5. Regression of OCF on Corporate Governance Variables

The dependent variable in panel A (OCFA3 ) is the 3-year averaged industry-adjusted operating cash flow for the target firm post change in control. The dependent variable in panel B (OCFA3 - OCFA-3) is the inter-temporal difference for the post-3-year and pre-3-year averaged industry-adjusted operating cash flow for the target firm. The other variables are defined in Tables 1 and 3 . In each cell the regression coefficient and t-statistics in parentheses are provided accordingly. ***, **, and * denote the significance level of $1 \%, 5 \%$, and $10 \%$, respectively. 


\begin{tabular}{|c|c|c|c|c|c|c|c|c|}
\hline \multirow{3}{*}{$\begin{array}{l}\text { Independent Variable } \\
\text { Intercept }\end{array}$} & \multicolumn{4}{|c|}{ Panel A: Dependent Variable: $\mathrm{OCF}_{3}^{\mathrm{A}}$} & \multicolumn{4}{|c|}{$\begin{array}{c}\text { Panel B: Dependent Variable }\left(\mathrm{OCF}_{3}^{\mathrm{A}}\right. \\
\left.-\mathrm{OCF}_{-3}^{\mathrm{A}}\right)\end{array}$} \\
\hline & 3.6158 & 1.0710 & -1.3390 & 0.1564 & 1.7226 & -0.9350 & -3.3490 & -1.7487 \\
\hline & $(1.559)$ & $(0.642)$ & $(-0.896)$ & $(0.108)$ & $(0.609)$ & $(-0.486)$ & $(-2.211)^{*}$ & $(-1.139)$ \\
\hline \multirow{2}{*}{$\begin{array}{l}\text { Proportion of Directors Represented by the } \\
\text { Controlling Shareholder }\end{array}$} & -0.0565 & & & & -0.0453 & & & \\
\hline & $(-1.676)^{*}$ & & & & $(-1.120)$ & & & \\
\hline \multirow{2}{*}{$\begin{array}{l}\text { Proportion of Supervisors Represented by the } \\
\text { Controlling Shareholder }\end{array}$} & & -0.0077 & & & & -0.0008 & & \\
\hline & & $(-0.427)$ & & & & $(-0.036)$ & & \\
\hline \multirow{2}{*}{$\begin{array}{l}\text { Proportion of Directors Represented by the } \\
\text { Second controlling shareholder }\end{array}$} & & & 0.0996 & & & & 0.1196 & \\
\hline & & & $(2.437)^{* *}$ & & & & $(2.850) * * *$ & \\
\hline \multirow{2}{*}{$\begin{array}{l}\text { Proportion of Supervisors Represented by the } \\
\text { Second controlling shareholder }\end{array}$} & & & & 0.0284 & & & & 0.0433 \\
\hline & & & & $(0.859)$ & & & & $(1.158)$ \\
\hline \multirow{2}{*}{ Cash flow rights (\%) } & 0.0631 & 0.0371 & 0.0968 & 0.0653 & 0.1851 & 0.0015 & 0.0021 & 0.2074 \\
\hline & $(0.556)$ & $(0.321)$ & $(0.878)$ & $(0.545)$ & $(1.295)$ & $(0.981)$ & $(1.573)$ & $(1.173)$ \\
\hline \multirow{2}{*}{ Voting rights - Cash flow rights (\%) } & -0.0300 & -0.0250 & -0.0220 & -0.0260 & -0.0270 & -0.0220 & -0.0199 & -0.0234 \\
\hline & $(-0.991)$ & $(-0.798)$ & $(-0.749)$ & $(-0.842)$ & $(-0.776)$ & $(-0.627)$ & $(-0.639)$ & $(-0.688)$ \\
\hline \multirow{2}{*}{ Dummy Manager Change } & 0.0124 & 0.0095 & 0.0141 & 0.0111 & 0.0065 & 0.0039 & 0.0107 & 0.0054 \\
\hline & $(0.993)$ & $(0.743)$ & $(1.185)$ & $(0.865)$ & $(0.448)$ & $(0.268)$ & $(0.810)$ & $(0.375)$ \\
\hline \multirow{2}{*}{ Dummy Participation } & -0.0222 & -0.0250 & -0.0198 & -0.0241 & -1.9120 & -1.9870 & -1.2460 & -1.9077 \\
\hline & $(-1.872)^{*}$ & $(-2.058)^{* *}$ & $(-1.741)^{*}$ & $(-1.993)^{*}$ & $(-1.067)$ & $(-1.089)$ & $(-0.749)$ & $(-1.067)$ \\
\hline \multirow{2}{*}{ Dummy Related } & 1.3663 & 1.3521 & 0.9787 & 1.1682 & 1.7696 & 1.6993 & 1.0351 & 1.3553 \\
\hline & $(1.081)$ & $(1.032)$ & $(0.801)$ & $(0.883)$ & (1.194) & (1.119) & $(0.751)$ & $(0.900)$ \\
\hline \multirow{2}{*}{ ln (assets) } & 0.1007 & 0.2349 & 0.1668 & 0.3579 & 1.6611 & 1.0562 & 1.5236 & 1.2775 \\
\hline & $(0.157)$ & $(0.354)$ & $(0.276)$ & $(0.554)$ & $(1.061)$ & $(0.695)$ & $(1.129)$ & $(0.870)$ \\
\hline \multirow{2}{*}{ Debt Ratio } & -0.0810 & -0.0840 & -0.0810 & -0.0870 & 0.0186 & -0.0045 & -0.0037 & 0.0002 \\
\hline & $(-2.255) * *$ & $(-2.257) * *$ & $(-2.375)^{* *}$ & $(-2.382) * *$ & $(0.244)$ & $(-0.061)$ & $(-0.055)$ & $(0.003)$ \\
\hline \multirow{2}{*}{ R\&D Ratio } & 0.3136 & 0.3582 & 0.4176 & 0.3525 & -0.6810 & -0.4780 & -0.3827 & -0.4250 \\
\hline & $(1.223)$ & $(1.329)$ & $(1.688)^{*}$ & $(1.343)$ & $(-1.123)$ & $(-0.816)$ & $(-0.723)$ & $(-0.737)$ \\
\hline \multirow{2}{*}{ Advertisement } & -18.7990 & -30.3260 & -32.6040 & -30.1120 & -98.2070 & -97.6650 & -104.1540 & -103.8980 \\
\hline & $(-0.492)$ & $(-0.787)$ & $(-0.914)$ & $(-0.789)$ & $(-1.808)^{*}$ & $(-1.752)^{*}$ & $(-2.087) * *$ & $(-1.908)^{*}$ \\
\hline Adjusted $\mathrm{R}^{2}$ & $24.06 \%$ & $18.43 \%$ & $31.27 \%$ & $20.11 \%$ & $7.62 \%$ & $4.31 \%$ & $23.21 \%$ & $7.93 \%$ \\
\hline
\end{tabular}

We further examine alternative performance measures, i.e. the industry-adjusted EPS and ROA, and summarize the results in Table 6 . To save space only the corporate governance variables are reported. The results in Table 6 conclude a similar finding that the proportion of directors represented by controlling shareholder is detrimental to industry-adjusted post-change performance measures. The existence of the second controlling shareholder reduces the possibility of wealth expropriation by the controlling shareholder and positively contributes to the post-change performance. Although marginally significant, the cash flow rights possessed by the controlling shareholder are positively related to the post-change performance of the target firm. We also conduct the test by the regression of the inter-temporal difference of the alternative performance measures on these corporate governance variables. The results further verify that the second controlling shareholder has positive influence and the controlling shareholder has negative influence one target's performance.

Someone might argue that accounting performance measures are backward-looking (e.g. 
Demsetz and Villalonga, 2001). Instead in Table 7 we use 3-year cumulative abnormal returns ${ }^{24}$ and the inter-temporal difference of Tobin's $Q$ into investigation. The cumulative abnormal return is calculated to accommodate the risk using single-index model. The estimation of systematic risk is conducted by regressing monthly returns of firms, from pre-84- through pre-25 month, on the value-weighted index of the Taiwan Stock Exchange ${ }^{25}$. Tobin' $Q$ is estimated by the proxy of equity price-to-book ratio. The result in panel $\mathrm{A}$ is insignificant although the voting/cash deviation is consistently and negatively related to the cumulated abnormal return. Healy, Palepu, and Ruback (1992) indicate that change in stock price is more likely to be confounded with economic gains and capital market inefficiency and therefore an inferior measure. The result in panel B shows that cash flow rights are significantly related to the improvement of firm's Tobin's Q. Even though less significant, the controlling shareholder's control over the board of directors and supervisors is negatively related to firm's performance while the second controlling shareholder's representation on the board is beneficial to the firm's performance.

The major contribution of this study is to portray that corporate governance is vital to dictate the post-change performance of the target firm. It is even more important to the variables used in previous literature. Another finding is that the board structure variables, namely the proportion of directors or supervisors represented by the controlling shareholder and the second controlling shareholder provides more resounding explanation upon the target's performance measure than the cash flow rights or the discrepancy between voting from cash flow rights do.

Table 6. Regression of EPS and ROA on Corporate Governance Variables

The dependent variables in Panel A are the 3-year averaged industry-adjusted EPS post change in control (EPSA3) and the inter-temporal difference in the post-3-year and pre-3-year averaged industry-adjusted EPS (EPSA3-EPSA-3). The independent variables in Panel B are ROAA3 and ROAA3 - ROAA-3, respectively. The definitions of the other variables including cash flow rights, the difference in voting rights and cash flow rights, Dummy participation, Dummy related, $\ln$ (assets), Debt ratio, R\&D ratio, and Advertising are listed in Table 1. To save space, the regression coefficients are not reported herein. The regression coefficient and t-statistics in parentheses are reported in each cell. ***, **, and $*$ denote the significance level of $1 \%, 5 \%$, and $10 \%$, respectively.

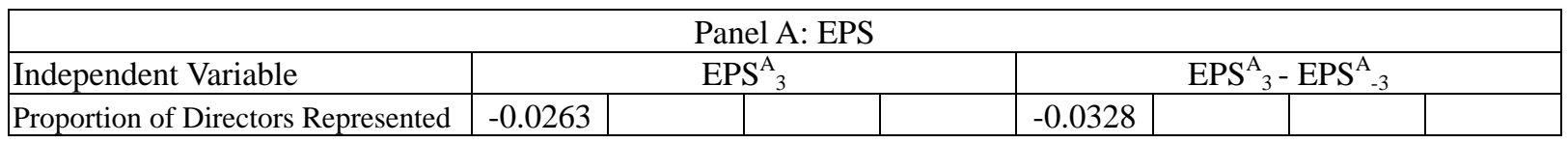

\footnotetext{
${ }^{24}$ For robustness, we also use 2-year performance measures in investigations and conclude a similar result.

${ }^{25}$ We also use alternative estimation period ranging from pre- 84 through pre- 1 month and conclude a similar result.
} 


\begin{tabular}{|c|c|c|c|c|c|c|c|c|}
\hline by the Controlling Shareholder & $(-1.723) *$ & & & & $(-1.482)$ & & & \\
\hline \multirow{2}{*}{$\begin{array}{l}\text { Proportion of Supervisors } \\
\text { Represented by the Controlling } \\
\text { Shareholder }\end{array}$} & & -0.0183 & & & & 0.0027 & & \\
\hline & & $(-0.022)$ & & & & $(0.243)$ & & \\
\hline \multirow{2}{*}{$\begin{array}{l}\text { Proportion of Directors Represented } \\
\text { by the Second controlling } \\
\text { shareholder }\end{array}$} & & & 0.0483 & & & & 0.0502 & \\
\hline & & & $\begin{array}{c}(2.822) * \\
* *\end{array}$ & & & & $\begin{array}{c}(2.154)^{*} \\
*\end{array}$ & \\
\hline \multirow{2}{*}{$\begin{array}{l}\text { Proportion of Supervisors } \\
\text { Represented by the Second } \\
\text { controlling shareholder }\end{array}$} & & & & 0.0182 & & & & 0.0298 \\
\hline & & & & $(1.207)$ & & & & (1.529) \\
\hline Cash flow rights & 0.0671 & 0.0553 & 0.0837 & 0.0727 & 0.0971 & 0.0828 & 0.1077 & 0.1133 \\
\hline \multirow[b]{2}{*}{ Voting rights - Cash flow rights } & $(1.293)$ & $(1.031)$ & $(1.695)^{*}$ & $(1.336)$ & $(1.281)$ & $(1.068)$ & $(1.461)$ & $(1.457)$ \\
\hline & $\begin{array}{l}0.0069 \\
(0.495)\end{array}$ & $\begin{array}{l}0.0092 \\
(0.640)\end{array}$ & $\begin{array}{c}0.0156 \\
(0.889)\end{array}$ & $\begin{array}{l}0.0086 \\
(0.607)\end{array}$ & $\begin{array}{c}-0.0051 \\
(-0.285 \\
)\end{array}$ & $\begin{array}{c}-0.0016 \\
(-0.086 \\
)\end{array}$ & $\begin{array}{c}-0.0045 \\
(-0.248 \\
)\end{array}$ & $\begin{array}{l}-0.0061 \\
(-0.160 \\
)\end{array}$ \\
\hline \multicolumn{9}{|c|}{ Panel B: ROA } \\
\hline & \multicolumn{4}{|c|}{$\mathrm{ROA}_{3}^{\mathrm{A}}$} & \multicolumn{4}{|c|}{$\mathrm{ROA}_{3}^{\mathrm{A}}-\mathrm{ROA}_{-3}^{\mathrm{A}}$} \\
\hline \multirow[b]{2}{*}{$\begin{array}{l}\text { Proportion of Directors Represented } \\
\text { by the Controlling Shareholder }\end{array}$} & -0.1378 & & & & -0.1352 & & & \\
\hline & $\begin{array}{c}(-2.365)^{*} \\
*\end{array}$ & & & & $(-1.842) *$ & & & \\
\hline \multirow{2}{*}{$\begin{array}{l}\text { Proportion of Supervisors } \\
\text { Represented by the Controlling } \\
\text { Shareholder }\end{array}$} & & -0.0318 & & & & -0.0046 & & \\
\hline & & $(-0.946)$ & & & & $(-0.125)$ & & \\
\hline \multirow{2}{*}{$\begin{array}{l}\text { Proportion of Directors Represented } \\
\text { by the Second controlling } \\
\text { shareholder }\end{array}$} & & & 0.2346 & & & & 0.2212 & \\
\hline & & & $\begin{array}{c}(3.002)^{*} \\
* *\end{array}$ & & & & $\begin{array}{c}(2.963)^{*} \\
* *\end{array}$ & \\
\hline \multirow{2}{*}{$\begin{array}{l}\text { Proportion of Supervisors } \\
\text { Represented by the Second } \\
\text { controlling shareholder }\end{array}$} & & & & 0.0918 & & & & 0.0778 \\
\hline & & & & $(1.561)$ & & & & $(1.159)$ \\
\hline Cash flow rights & 0.2254 & 0.1688 & 0.3994 & 0.2396 & 0.4003 & 0.3283 & 0.3545 & 0.4202 \\
\hline \multirow[b]{2}{*}{ Voting rights - Cash flow rights } & $(1.075)$ & $(0.786)$ & $(1.501)$ & $(1.077)$ & $(1.587)$ & $(1.282)$ & $(1.500)$ & $(1.596)$ \\
\hline & $\begin{array}{l}0.0077 \\
(0.145)\end{array}$ & $\begin{array}{l}0.0184 \\
(0.328)\end{array}$ & $\begin{array}{l}0.0134 \\
(0.155)\end{array}$ & $\begin{array}{l}0.0167 \\
(0.303)\end{array}$ & $\begin{array}{l}-0.0529 \\
(-0.871)\end{array}$ & $\begin{array}{l}-0.0410 \\
(-0.656)\end{array}$ & $\begin{array}{l}-0.0376 \\
(-0.656)\end{array}$ & $\begin{array}{l}-0.0434 \\
(-0.712)\end{array}$ \\
\hline
\end{tabular}

Table 7. Regression of Cumulative Abnormal Return and Tobin's Q on Corporate Governance Variables

The dependent variable in panel A (3 year CAR) is 3-year cumulative average abnormal return for firms than change control of which risk is adjusted by the single index model The dependent variable in panel B (QA3 -QA-3) is the inter-temporal difference for the post-3-year and pre-3-year averaged industry-adjusted Tobin's $Q$ for firms that change in control. The other variables are defined in Tables 1 and 3. In each cell the regression coefficient and t-statistics in parentheses are provided accordingly. ***, **, and * denote the significance level of $1 \%, 5 \%$, and $10 \%$, respectively.

\begin{tabular}{|l|c|c|c|c|c|c|c|c|}
\hline \multirow{2}{*}{ Independent Variable } & \multicolumn{4}{|c|}{ Panel A: Dependent Variable: 3-year } & \multicolumn{3}{c|}{ Panel B: Dependent Variable $\left(\mathrm{Q}^{\mathrm{A}}{ }_{3}\right.$} \\
\hline \multirow{3}{*}{ Intercept } & 23.1155 & -41.3079 & -36.7378 & -15.7037 & -0.1275 & -0.2238 & $\begin{array}{c}-0.4368 \\
(-2.319) *\end{array}$ & -0.3401 \\
& $(0.367)$ & $(-0.936)$ & $(-0.8069)$ & $(-0.409)$ & $(-0.378)$ & $(-1.057)$ & $\left(\begin{array}{c}(-2.896)^{*} \\
*\end{array}\right.$ & \\
\hline
\end{tabular}




\begin{tabular}{|c|c|c|c|c|c|c|c|c|}
\hline $\begin{array}{l}\text { Proportion of Directors } \\
\text { Represented by the Controlling } \\
\text { Shareholder }\end{array}$ & $\begin{array}{l}-0.7078 \\
(-0.763)\end{array}$ & & & & $\begin{array}{l}-0.0028 \\
(-0.562)\end{array}$ & & & \\
\hline $\begin{array}{l}\text { Proportion of Supervisors } \\
\text { Represented by the Controlling } \\
\text { Shareholder }\end{array}$ & & $\begin{array}{l}0.3256 \\
(0673)\end{array}$ & & & & $\begin{array}{l}-0.0434 \\
(-0.183)\end{array}$ & & \\
\hline $\begin{array}{l}\text { Proportion of } \begin{array}{r}\text { Directors } \\
\text { Represented by the Second } \\
\text { controlling shareholder }\end{array} \\
\end{array}$ & & & $\begin{array}{l}0.4333 \\
(0.389)\end{array}$ & & & & $\begin{array}{l}0.0073 \\
(1.396)\end{array}$ & \\
\hline $\begin{array}{l}\text { Proportion of Supervisors } \\
\text { Represented by the Second } \\
\text { controlling shareholder }\end{array}$ & & & & $\begin{array}{l}-0.6074 \\
(-0.677)\end{array}$ & & & & $\begin{array}{l}0.0027 \\
(0.613)\end{array}$ \\
\hline Cash flow rights $(\%)$ & $\begin{array}{l}0.1437 \\
(0.044)\end{array}$ & $\begin{array}{l}-0.1182 \\
(-0.036)\end{array}$ & $\begin{array}{l}0.1549 \\
(0.046)\end{array}$ & $\begin{array}{l}-0.6882 \\
(-0.204)\end{array}$ & $\begin{array}{c}0.0397 \\
(2.639)^{*}\end{array}$ & $\begin{array}{c}0.0377 \\
(2.591)^{*} \\
*\end{array}$ & $\begin{array}{c}0.0470 \\
(2.821)^{*} \\
* *\end{array}$ & $\begin{array}{c}0.0411 \\
(2.658)^{*} \\
*\end{array}$ \\
\hline $\begin{array}{l}\text { Voting rights }- \text { Cash flow rights } \\
(\%)\end{array}$ & $\begin{array}{l}-1.3282 \\
(-1.603) \\
\end{array}$ & $\begin{array}{l}-1.2525 \\
(-1.515) \\
\end{array}$ & $\begin{array}{l}-1.2464 \\
(-1.498) \\
\end{array}$ & $\begin{array}{l}-1.2516 \\
(-1.514) \\
\end{array}$ & $\begin{array}{l}0.0065 \\
(1.537) \\
\end{array}$ & $\begin{array}{l}0.0067 \\
(1.560) \\
\end{array}$ & $\begin{array}{l}0.0070 \\
(1.661) \\
\end{array}$ & $\begin{array}{l}0.0062 \\
(1.575) \\
\end{array}$ \\
\hline Dummy Manager Change & $\begin{array}{l}-24.5743 \\
(-0.719) \\
\end{array}$ & \begin{tabular}{|c|}
-30.4313 \\
$(-0.900)$ \\
\end{tabular} & $\begin{array}{l}-27.0818 \\
(-0.790) \\
\end{array}$ & $\begin{array}{l}-32.0893 \\
(-0.9043) \\
\end{array}$ & \begin{tabular}{|l|}
-0.2175 \\
$(-1.322)$ \\
\end{tabular} & $\begin{array}{l}-0.2227 \\
(-1.357) \\
\end{array}$ & $\begin{array}{l}-0.1932 \\
(-1.192) \\
\end{array}$ & \begin{tabular}{|l|}
-0.2195 \\
$(-1.349)$ \\
\end{tabular} \\
\hline Dummy Participation & $\begin{array}{c}-24.1600 \\
(-0.744) \\
\end{array}$ & $\begin{array}{c}-27.6344 \\
(-0.857) \\
\end{array}$ & $\begin{array}{r}-25.3525 \\
(-0.772) \\
\end{array}$ & $\begin{array}{c}-29.2614 \\
(-0.905) \\
\end{array}$ & $\begin{array}{l}-0.2115 \\
(-1.012) \\
\end{array}$ & $\begin{array}{l}-0.2106 \\
(-1.004) \\
\end{array}$ & $\begin{array}{l}-0.1709 \\
(-0.827) \\
\end{array}$ & $\begin{array}{l}-0.2111 \\
(-1.011) \\
\end{array}$ \\
\hline Dummy Related & $\begin{array}{c}16.2922 \\
(0.474)\end{array}$ & $\begin{array}{c}19.6631 \\
(0.565) \\
\end{array}$ & $\begin{array}{c}14.4288 \\
(0.412)\end{array}$ & $\begin{array}{c}21.4288 \\
(0.605) \\
\end{array}$ & $\begin{array}{l}0.0340 \\
(0.196)\end{array}$ & $\begin{array}{l}0.0209 \\
(0.119) \\
\end{array}$ & $\begin{array}{l}-0.0108 \\
(-0.063)\end{array}$ & $\begin{array}{l}0.0084 \\
(0.048) \\
\end{array}$ \\
\hline $\ln$ (assets) & $\begin{array}{l}9.5833 \\
(0.572)\end{array}$ & $\begin{array}{c}13.4036 \\
(0.795)\end{array}$ & $\begin{array}{c}10.9317 \\
(0.652)\end{array}$ & $\begin{array}{c}10.8450 \\
(0.647)\end{array}$ & $\begin{array}{l}-0.1316 \\
(-0.721)\end{array}$ & $\begin{array}{l}-0.1546 \\
(-0.884)\end{array}$ & $\begin{array}{l}-0.1401 \\
(-0.835)\end{array}$ & $\begin{array}{l}-0.1548 \\
(-0.902)\end{array}$ \\
\hline Debt Ratio & $\begin{array}{r}1.1886 \\
(1.311) \\
\end{array}$ & $\begin{array}{l}0.9109 \\
(0.993) \\
\end{array}$ & $\begin{array}{c}1.0768 \\
(1.195) \\
\end{array}$ & $\begin{array}{c}1.0061 \\
(1.120) \\
\end{array}$ & $\begin{array}{c}0.0105 \\
(1.179) \\
\end{array}$ & $\begin{array}{c}0.0092 \\
(1.078) \\
\end{array}$ & $\begin{array}{c}0.0091 \\
((1.093) \\
\end{array}$ & \begin{tabular}{|c|}
0.0094 \\
$(1.097)$ \\
\end{tabular} \\
\hline R\&D Ratio & $\begin{array}{l}3.2186 \\
(0.530) \\
\end{array}$ & $\begin{array}{l}2.8069 \\
(0.452) \\
\end{array}$ & $\begin{array}{r}4.0740 \\
(0.658) \\
\end{array}$ & $\begin{array}{l}3.1609 \\
(0.515) \\
\end{array}$ & $\begin{array}{l}0.0391 \\
(0.553) \\
\end{array}$ & $\begin{array}{c}0.0521 \\
(0.773) \\
\end{array}$ & \begin{tabular}{|c|}
0.0573 \\
$(0.870)$ \\
\end{tabular} & $\begin{array}{r}0.0548 \\
(0.813) \\
\end{array}$ \\
\hline Advertisement & $\begin{array}{l}1706.05 \\
(1.763)^{*}\end{array}$ & $\begin{array}{c}1443.03 \\
(1.580)\end{array}$ & $\begin{array}{c}1486.70 \\
(1.626)\end{array}$ & $\begin{array}{c}1482.57 \\
(1.629)\end{array}$ & $\begin{array}{l}-12.5222 \\
(-1.976)^{*}\end{array}$ & $\begin{array}{l}-12.1552 \\
(-1.894)^{*}\end{array}$ & $\begin{array}{c}-12.8841 \\
(-2.077)^{*} \\
*\end{array}$ & $\left\{\begin{array}{l}-12.8746 \\
(-2.024) *\end{array}\right.$ \\
\hline Adjusted $\mathrm{R}^{2}$ & $6.62 \%$ & $6.28 \%$ & $5.48 \%$ & $6.30 \%$ & $0.26 \%$ & $0.02 \%$ & $3.69 \%$ & $0.62 \%$ \\
\hline
\end{tabular}

\subsection{Corporate Governance and Financial Distress}

The evidence so far indicates that excess intervention by the controlling shareholder sparks poor post-change performance. Also of interest is whether his intervention through obtaining an excess proportion of directors or engaging in management practices triggers a higher level of financial distress. Financial distress is defined in two ways. The first one is that firms fail to pay principal/interest on schedule as to renegotiate with creditors for delaying or abating cash payment. The second one is when listed companies that have lost more than half of capital stock are mandatory traded at $100 \%$ margin. There are 15 firms confronted with financial distress post control change. Logistical estimation is applied with the dependent variable of 1 if the target firm is confronted with financial distress after change in control, and 0 otherwise. The results are summarized in Table $8^{26}$.

\footnotetext{
${ }^{26}$ Someone might propose that performance rather than board structure is directly related to financial distress. We also include the performance measure into the logistic model and find a similar result even though the board structure variables are less significant.
} 
The results show that the higher the proportion of directors represented by the controlling shareholder, the more likely that the target firm will be trapped in financial distress. Specifically, one percent increase of the proportion of directors represented by the controlling shareholder leads to $0.52 \%$ increase of the likelihood that the target firm would be trapped in financial distress. Moreover, the proportion of supervisors controlled by the controlling shareholder is also positively related to the likelihood of target's financial distress, albeit marginally significant. Moreover, acquisitions involving firms in a related industry are less likely to lapse into financial distress, echoing the finding of Healy et al. (1992).

Note that leverage is only marginally significant to discern the propensity that firms change in control would be financially distressed. . We examine the debt ratio and find that in general firms that were confronted and firms that were not confronted with financial distress increased their debt ratio. The three-year averaged debt ratio was $52.57 \%$ before the change and $57.75 \%$ after the change. However, a further examination of the industry-adjusted debt ratio that was included in the regression shows that for firms that were not confronted with financial distress, non-financial firms increased while financial firms decreased the debt ratio. The non-financial firms that were confronted with financial ratio increased the ratio. Moreover, the cross-section difference in industry-adjusted debt ratio between financial distressed firms and non-financial distressed firms is only marginally significant at $10 \%$ level. This might blur the relation between debt ratio and financial distress.

Table 8. Logistic Model Estimates for the Determinants of Financial Distress

Logistic regression is applied herein to estimate the determinants for financial distress. The dependent variable, dummy Financial Distress, is assigned the value of 1 if the target firm is confronted with financial distress after acquisition, and 0 otherwise. The other variables are defined in Tables 2 and 4. The regression coefficient and p-value (in parentheses) are reported in each cell, accordingly. $* * *, * *$, and $*$ denote the significance level of $1 \%, 5 \%$, and $10 \%$, respectively.

\begin{tabular}{|c|c|c|c|c|}
\hline Independent Variable & \multicolumn{4}{|c|}{ Dependent Variable: Dummy Financial Distress } \\
\hline \multirow{2}{*}{ Intercept } & -6.1507 & -3.1000 & -1.2821 & -1.9506 \\
\hline & $(0.005)$ & $(0.017)$ & $(0.223)$ & $(0.062)$ \\
\hline \multirow{2}{*}{$\begin{array}{l}\text { Proportion of Directorates Represented by } \\
\text { the Controlling Shareholder }\end{array}$} & 0.0693 & & & \\
\hline & $(0.019)^{* *}$ & & & \\
\hline \multirow{2}{*}{$\begin{array}{l}\text { Proportion of Supervisors Represented by } \\
\text { the Controlling Shareholder }\end{array}$} & & 0.0200 & & \\
\hline & & $(0.105)$ & & \\
\hline \multirow{2}{*}{$\begin{array}{l}\text { Proportion of Directorates Represented by } \\
\text { the Second controlling shareholder }\end{array}$} & & & -0.0249 & \\
\hline & & & $(0.391)$ & \\
\hline \multirow{2}{*}{$\begin{array}{l}\text { Proportion of Supervisors Represented by } \\
\text { the Second controlling shareholder }\end{array}$} & & & & 0.0078 \\
\hline & & & & $(0.739)$ \\
\hline
\end{tabular}




\begin{tabular}{|l|c|c|c|c|}
\hline \multirow{2}{*}{ Cash flow rights (\%) } & 0.1298 & 0.1489 & 0.1139 & 0.1476 \\
\cline { 2 - 5 } & $(0.197)$ & $(0.117)$ & $(0.180)$ & $(0.122)$ \\
\hline \multirow{2}{*}{ Voting rights - Cash flow rights (\%) } & 0.0108 & 0.0033 & 0.0010 & 0.0025 \\
\cline { 2 - 5 } & $(0.627)$ & $(0.871)$ & $(0.960)$ & $(0.906)$ \\
\hline \multirow{2}{*}{ Dummy Participation } & 0.1442 & 0.4806 & 0.1845 & 0.2331 \\
\cline { 2 - 5 } & $(0.878)$ & $(0.565)$ & $(0.818)$ & $(0.772)$ \\
\hline \multirow{2}{*}{ Dummy Related } & -2.7566 & -2.3228 & -2.0861 & -2.3214 \\
\cline { 2 - 5 } & $(0.044)^{* *}$ & $(0.055)^{*}$ & $(0.063)^{*}$ & $(0.045)^{* *}$ \\
\hline \multirow{2}{*}{ Debs Ratio } & 0.6913 & 0.5624 & 0.4454 & 0.3790 \\
\cline { 2 - 5 } & $(0.251)$ & $(0.248)$ & $(0.332)$ & $(0.398)$ \\
\hline \multirow{2}{*}{ R\&D Ratio } & 0.0429 & 0.0422 & 0.0456 & 0.0481 \\
\cline { 2 - 5 } & $(0.129)$ & $(0.121)$ & $(0.084)^{*}$ & $(0.067)^{*}$ \\
\hline \multirow{2}{*}{ Advertisement } & 0.0749 & -0.0356 & -0.0209 & -0.0137 \\
\cline { 2 - 5 } & $(0.748)$ & $(0.876)$ & $(0.930)$ & $(0.963)$ \\
\hline & -31.9113 & -21.9382 & -17.1011 & -18.4553 \\
\cline { 2 - 5 } & $(0.179)$ & $(0.324)$ & $(0.427)$ & $(0.400)$ \\
\hline
\end{tabular}

\subsection{Robustness Check}

In Section 5.1 we examine whether the corporate governance variables affected the post-change performance and the inter-temporal change of performance measures. One robustness check is to test whether the corporate governance variables changed significantly, and whether the change in corporate governance variables is related to the change in performance.

In an unreported result we find that the proportion of directors represented by the controlling shareholder is $50.02 \%$ for pre-acquisition and $66.34 \%$ for post-change, with a significant difference of $16.32 \%$ at the $1 \%$ significance level. The proportion of supervisors controlled by the controlling shareholder is $47.43 \%$ and $61.96 \%$ for pre- and post-change, respectively. The difference is $14.53 \%$ at the $10 \%$ significance level. In contrast, the pre-acquisition cash flow rights of the controlling shareholder are $13.32 \%$, which were then reduced to $6.35 \%$ after the change in control. A more prominent case is that the discrepancy between voting and cash flow rights increased from $2.73 \%$ before to $16.09 \%$ after the change. This illustrates that the controlling shareholder levered his control through acquiring directorate and supervisor seats beyond the merits of his cash flow rights.

We further examine whether the change in the corporate governance variable is connected to the change in performance. The change in performance is regressed on the change in governance variables. An unreported result illustrates that the intertemporal change of the proportion of directors represented by the controlling shareholder is negatively related to the inter-temporal change of industry-adjusted ROE and ROA at the $10 \%$ significance level, and negatively related to the intertemporal change in EPS and OCF, albeit less significant. The inter-temporal change of cash flow rights is positively related to the inter-temporal change of ROE (EPS) with the significance level of $11.5 \%$ (10.6\%). We 
also investigate a subsample that excluded cases of cash proxy fight and conclude a similar result.

\section{Concluding Remarks}

This study collected 46 observations of change in control from 1991 to 1999. Even though the market of corporate control disciplined the poor-performing managers, the performance measures of these firms that change in control were even worse than their pre-change level.

Most of the existing literature focus on the type of acquisition, method of payment, size effect, firm's attributes and industry relationship. This study provides an alternative perspective and evidences that corporate governance variables do dictate the post-change performance of the targets. Our empirical results show that the higher the proportion of directors controlled by the controlling shareholder, the lower the post-change performance is. In contrast, the second controlling shareholder provides a governance function to prevent wealth exploitation by the controlling shareholder when he/she obtains more directorate seats on the board. The post-change performance of the target tended to be higher when the controlling shareholder has higher cash flow rights. Finally, a target firm is prone to be trapped in financial distress when the controlling shareholder involved in the board structure.

Our results are robust to alternative specifications. First of all, the results from different performance measures, namely ROE, OCF, EPS, ROA, cumulative abnormal returns, and Tobin's Q are consistent. Moreover, the results from the cross-sectional relations are similar to the relations by taking an inter-temporal difference. Alternative specifications further verify that corporate governance is important to dictate the post-change performance of a target firm.

The results of this study imply that the new controller's motivation does matter in affecting the target's performance. The governance structure haggled between controlling shareholder and the second controlling shareholder dictates the power structure, which in turn affects the post-change performance of the target firm, to an extent beyond the other variables that have been discussed in previous literatures.

We did not specifically cover another thread of studies that emphasize ethical values at the top (Schwartz, Dunfee, and Kline, 2005; Rosanas and Velilla, 2005). We totally agree that the universal core ethical values such as honesty, integrity, loyalty, responsibility, fairness, and citizenship, do affect the long-term survival and lead to the best interest of the corporation. However, our findings might potentially contribute to this thread of studies on the onset of examining controlling owner's motives that are manifested in 
ownership structure and board structure. Controlling owners are much emotionally connected to the firms that they founded than the firms that were acquired. Therefore, demand for their abidance to ethical values would be much applicable to the former than to the latter. Further researches could portray the difference on how to motivate the top-level constituencies for firms that change-in-control versus firms that did not.

\section{References}

Admati, A., P. Pfleiderer, \& J. Zechner, (1994). Controlling shareholder Activism, Risk Sharing and Financial Market Equilibrium, Journal of Political Economy, 102, 1097-1130. http://dx.doi.org/10.1086/261965

Agrawal, A., J. F. Jaffe, \& G. N. Mandelker, (1992). The Post-Merger Performance of Acquiring Firms: A Re-examination of an Anomaly, Journal of Finance, 47, 1605-1621. http://dx.doi.org/10.1111/j.1540-6261.1992.tb04674.x

Ambrose, B. W., \& W. L. Megginson, (1992). The Role of Asset Structure, Ownership Structure, and Takeover Defenses in Determining Acquisition Likelihood, Journal of Financial Quantitative Analysis, 27, 575-589. http://dx.doi.org/10.2307/2331141

Bebchuk, L. A., R. Kraakman, \& G. Triantis, (2000). Stock Pyramids, Cross-Ownership, and Dual Class Equity: The Creation and Agency Costs of Separating Control from Cash Flow Rights, in Concentrated Corporate Ownership, R. Morck ed., 295-315.

Bethel, J. E., J. P. Liebeskind, \& T. Opler, (1998). Block Share of Purchases and Corporate Performance, Journal of Finance, 53, 605-634. http://dx.doi.org/10.1111/0022-1082.244195

Bhagat, S., \& B. Black. (2002). The Non-correlation between Board Independence and Long-term Firm Performance, Journal of Corporate Law, 27, 231

Brickley, J. A., R. C. Lease, \& C. W. Smith. (1988). Ownership Structure and Voting on Antitakeover Amendments, Journal of Financial Economics, 20, 267-291. http://dx.doi.org/10.1016/0304-405X(88)90047-5

Butz, D. A., (1994). How do Large Minority Shareholders Wield Control? Management and Decision Economics, 15, 291-298. http://dx.doi.org/10.1002/mde.4090150404

Chan, S., J. Martin, \& J. Kensinger, (1990). Corporate Research and Development Expenditures and Share Value, Journal of Financial Economics, 26, 255-276. http://dx.doi.org/10.1016/0304-405X(90)90005-K

Claessens, S., S. Djankov, \& L. H. P. Lang. (2000). The Separation of Ownership and 
Control in East Asian Corporation, Journal of Financial Economics, 58, 81-112. http://dx.doi.org/10.1016/S0304-405X(00)00067-2

Claessens, S., S. Djankov, J. Fan, \& H. P. Lang (2002). Disentangling the Incentive and Entrenchment Effects of Large Shareholdings, Journal of Finance, 57, 2741-2772. http://dx.doi.org/10.1111/1540-6261.00511

Comment, R., \& G. W. Schwert. (1995). Poison or Placebo? Evidence on the Deterrent and Wealth Effects of Modern Anti-Takeover Measures, Journal of Financial Economics, 39, 3-43. http://dx.doi.org/10.1016/0304-405X(94)00823-J

Connelly, S., W. Helton-Fauth, \& M. D. Mumford. (2004). A Managerial In-Basket Study of the Impact of Trait Emotions on Ethical Choice, Journal of Business, 51, 245-267

Craswell, A., S. Taylor, \& R. Saywell (1997). Ownership Structure and Corporate Performance: Australian evidence, Pacific-Basin Finance Journal, 5, 301-323. http://dx.doi.org/10.1016/S0927-538X(96)00028-5

Crutchley, C. E., \& R. S. Hansen. (1989). A Test of the Agency Theory of Managerial Ownership, Corporate Leverage, and Corporate Dividends, Financial Management, 18, 36-46. http://dx.doi.org/10.2307/3665795

Demsetz, H., \& B. Villalonga. (2001). Ownership Structure and Corporate Performance, $\begin{array}{llll}\text { Journal of Corporate } \quad \text { Finance, } & 7, & \text { 209-233. }\end{array}$ http://dx.doi.org/10.1016/S0929-1199(01)00020-7

Demsetz, H., \& K. Lehn. (1985). The Structure of Corporate Ownership: Causes and Consequences, Journal of Political economy, 93, 1155-1177. http://dx.doi.org/10.1086/261354

Faccio, M., \& L. H. P. Lang. (2002). The Separation of Ownership and Control: An Analysis of Ultimate Ownership in Western European Corporations. Journal of Financial Economics, 65, 365-395. http://dx.doi.org/10.1016/S0304-405X(02)00146-0

Flower, K. L., \& D. Schmidt. (1989). Determinants of Tender Offer Post-change Financial Performance. Strategic Management Journal, 339-350.

Gaudine, A., \& L. Thorne. (2001). Emotion and Ethical Decision-Making in Organizations, Journal of Business Ethics, 31, 175-187. http://dx.doi.org/10.1023/A:1010711413444

Gomes, A., (2000). Going Public without Governance: Managerial Reputation Effects," Journal of Finance, 55, 615-646. http://dx.doi.org/10.1111/0022-1082.00221 
Grossman, S., \& O. Hart. (1988). One-Share, One-Vote, and the Market for Corporate Control, Journal of Financial Economics, 20, 175-202. http://dx.doi.org/10.1016/0304-405X(88)90044-X

Healy, P., K. G. Palepu, \& R. S. Ruback. (1992). Does Corporate Performance Improve after Mergers? Journal of Financial Economics, 31, 135-175. http://dx.doi.org/10.1016/0304-405X(92)90002-F

Healy, P., K. G. Palepu, \& R. S. Ruback. (1997). Which takeovers are profitable? Strategic or Financial, Sloan Management Review, 38, 45-57.

Huddart, S. (1993). The Effect of a Large Shareholder on Corporate Value, Management Science, 39, 1407-1421. http://dx.doi.org/10.1287/mnsc.39.11.1407

Jarrell, G. A., \& A. B. Poulsen. (1987). Shark Repellents and Stock Prices: The Effects of Anti-takeover Charter Amendments Since 1980, Journal of Financial Economics, 19, 127-168 http://dx.doi.org/10.1287/mnsc.39.11.1407

Jensen, G. R., D. P. Solberg, \& T. S. Zorn. (1992). Simultaneous Determination of Insider Ownership, Debt, and Dividend Policies," Journal of Financial and Quantitative Analysis, 27, 247-263. http://dx.doi.org/10.2307/2331370

La Porta, R., F. Lopez-de-Silanes, A. Shleifer, \& R. Vishny (1998). Law and finance, Journal of Political Economy, 106, 1113-1155. http://dx.doi.org/10.1086/250042

La Porta, R., F. Lopez-de-Silanes, A. Shleifer, \& R. W. Vishny. (2002). Investor Protection and Corporate Valuation, Journal of Finance, 57, 1147-1171. http://dx.doi.org/10.1111/1540-6261.00457

La Porta, R., F. Lopez-de-Silanes, and A. Shleifer. (1999). Corporate Ownership around the World, Journal of Finance, 54, 471-517. http://dx.doi.org/10.1111/0022-1082.00115

Lee, K., \& J. N. Allen. (2002). Organizational Citizenship Behavior and Workplace Deviance: The Role of Affect and Cognitions, Journal of Applied Psychology, 87, 131-142. http://dx.doi.org/10.1037/0021-9010.87.1.131

Lerner, J. S., \& D. Keltner. (2000). Beyond Valence: Toward a Model of Emotion-Specific Influences on Judgment and Choice", Cognition and Emotion, 14, 473-493. http://dx.doi.org/10.1080/026999300402763

Lewis, K., (2000). When Leaders Display Emotion: How Followers Respond to Negative Emotional Expression of Male and Female Leaders, Journal of Organizational Behavior, 
http://dx.doi.org/10.1002/(SICI)1099-1379(200003)21:2<221::AID-JOB36>3.0.CO;2-0

Manne, H. G. (1965). Mergers and market for Corporate Control, Journal of Political Economy, 73, 110-120. http://dx.doi.org/10.1086/259000

Martin, K. J., \& J. J. McConnell. (1991). Corporate Performance, Corporate Takeovers, and Management Turnover, Journal of Finance, 46, 671-687. http://dx.doi.org/10.1111/j.1540-6261.1991.tb02679.x

McConnell, J., \& C. Muscarella. (1985). Corporate Capital Expenditure Decisions and the Market Value of the Firm, Journal of Financial Economics, 14, 399-422. http://dx.doi.org/10.1016/0304-405X(85)90006-6

McConnell, J. J., \& H. Servaes. (1990). Additional Evidence on Equity Ownership and Corporate Value, Journal of Financial Economics, 27, 595-612. http://dx.doi.org/10.1016/0304-405X(90)90069-C

Morck, R., A. Shleifer, \& R. Vishny. (1988). Management Ownership and Market Valuation: An Empirical Analysis, Journal of Financial Economics, 20, 293-315. http://dx.doi.org/10.1016/0304-405X(88)90048-7

Morck, R., A. Shleifer, \& R. Vishny. (1989). Alternative Mechanisms for Corporate Control, American Economic Review, 79, 842-852

Palepu, K., (1985). Diversification Strategy, Profit Performance and the Entropy Measure, Strategic Management Journal, $6, \quad 239-255$. http://dx.doi.org/10.1002/smj.4250060305

Rosanas, J., \& M. Velilla. (2005). The Ethics of Management Control Systems: Developing Technical and Moral Values, Journal of Business Ethics, 57, 83-96. http://dx.doi.org/10.1007/s10551-004-3826-1

Schwartz, M., T. Dunfee, \& M. Kline. (2005). Tone at the Top: An Ethics Code for $\begin{array}{lllll}\text { Directors? Journal of } & \text { Business }\end{array}$ http://dx.doi.org/10.1007/s10551-005-1390-y

Shivdasani, A., \& D. Yermack. (1999). CEO Involvement in the Selection of New Board members: An Empirical Analysis, Journal of Finance, 54, 1829-1853. http://dx.doi.org/10.1111/0022-1082.00168

Shleifer, A., \& R. Vishny. (1986). Large Shareholders and Corporate Control," Journal of Political Economy, 94, 461-488. http://dx.doi.org/10.1086/261385

Shleifer, A., \& R. Vishny. (1997). A Survey of Corporate Governance, Journal of 


\section{Macrothink \\ Business and Economic Research \\ ISSN 2162-4860 2014, Vol. 4, No. 2}

Financial Economics, 52, 737-783.

Weiss, H. M, K. Suckow, \& R. Cropanzano. (1999). Effects of Justice Conditions on Discrete Emotions, Journal of Applied Psychology, 84, 786-794. http://dx.doi.org/10.1037/0021-9010.84.5.786

Xiang, B., \& G. Zhang. (1996). Large Shareholder Expropriation and Corporate Ownership Structure, The 1996 APFA/PACAP Financial Conference and the Chinese Finance Association Annual Conference, Taiwan.

Yeh, Y. H., T. S. Lee, \& T. Woidtke. (2001). Family Control and Corporate Governance: Evidence from Taiwan, International Review of Finance, 2, 21-48. http://dx.doi.org/10.1111/1468-2443.00014

Yeh, Y. H., T. S. Lee, \& P. G. Shu. (2008). The Agency Problems Embedded in Firm's Equity Investment, Journal of Business Ethics, 79, 151-166. http://dx.doi.org/10.1007/s10551-007-9387-3

\section{Copyright Disclaimer}

Copyright for this article is retained by the author(s), with first publication rights granted to the journal.

This is an open-access article distributed under the terms and conditions of the Creative Commons Attribution license (http://creativecommons.org/licenses/by/3.0/). 